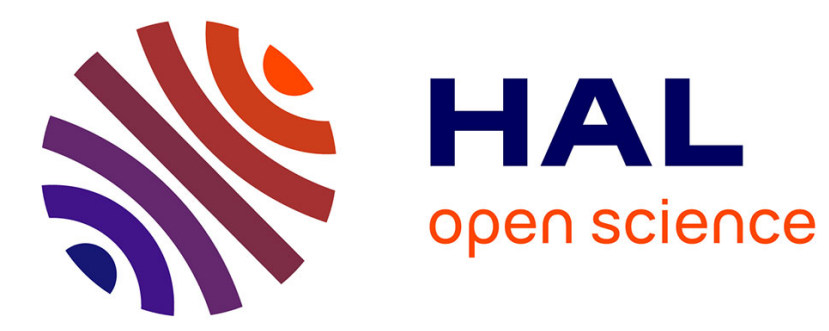

\title{
Investment climate, outward orientation and manufacturing firm productivity: New empirical evidence
}

Marie-Ange Véganzonès-Varoudakis, Hoang Thanh Mai Nguyen

\section{To cite this version:}

Marie-Ange Véganzonès-Varoudakis, Hoang Thanh Mai Nguyen. Investment climate, outward orientation and manufacturing firm productivity: New empirical evidence. Applied Economics, 2018, 50 (53), pp.5766-5794. 10.1080/00036846.2018.1488065 . halshs-01618733v2

\section{HAL Id: halshs-01618733 \\ https://shs.hal.science/halshs-01618733v2}

Submitted on 5 Oct 2018

HAL is a multi-disciplinary open access archive for the deposit and dissemination of scientific research documents, whether they are published or not. The documents may come from teaching and research institutions in France or abroad, or from public or private research centers.
L'archive ouverte pluridisciplinaire HAL, est destinée au dépôt et à la diffusion de documents scientifiques de niveau recherche, publiés ou non, émanant des établissements d'enseignement et de recherche français ou étrangers, des laboratoires publics ou privés. 


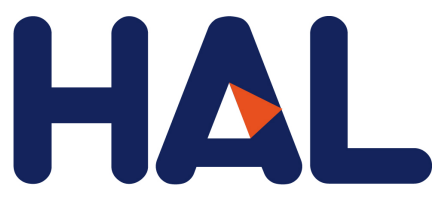

archives-ouvertes

\section{Investment climate, outward orientation and manufacturing firm productivity: New empirical evidence}

Mai Nguyen, Marie-Ange Veganzones-Varoudakis

\section{To cite this version:}

Mai Nguyen, Marie-Ange Veganzones-Varoudakis. Investment climate, outward orientation and manufacturing firm productivity: New empirical evidence. Publié dans: Applied Economics, Taylor

Francis (Routledge), 2018, pp.1 - 29. 2017. <halshs-01618733>

\section{HAL Id: halshs-01618733 \\ https://halshs.archives-ouvertes.fr/halshs-01618733}

Submitted on 18 Oct 2017

HAL is a multi-disciplinary open access archive for the deposit and dissemination of scientific research documents, whether they are published or not. The documents may come from teaching and research institutions in France or abroad, or from public or private research centers.
L'archive ouverte pluridisciplinaire HAL, est destinée au dépôt et à la diffusion de documents scientifiques de niveau recherche, publiés ou non, émanant des établissements d'enseignement et de recherche français ou étrangers, des laboratoires publics ou privés. 


\section{SÉRIE ÉTUDES ET DOCUMENTS}

\section{Investment climate, outward orientation and manufacturing firm productivity: New empirical evidence}

Hoang Thanh Mai Nguyen

Marie-Ange Véganzonès-Varoudakis

Études et Documents $\mathrm{n}^{\circ} 17$

October 2017

To cite this document:

Nguyen H. T. M., Véganzonès-Varoudakis M. A. (2017) "Investment climate, outward orientation and manufacturing firm productivity: New empirical evidence", Études et Documents, $\mathrm{n}^{\circ} 17, \mathrm{CERDI}$. http://cerdi.org/production/show/id/1889/type_production_id/1

CERDI

65 BD. F. MITTERRAND

63000 CLERMONT FERRAND - FRANCE

TEL. + 33473177400

$\mathrm{FAX}+33473177428$

www.cerdi.org 


\section{The authors}

Hoang Thanh Mai Nguyen

Research Fellow, KU Leuven, Belgium \& OECD Development Center, Paris, France.

E-mail: nguyen_mai94@yahoo.fr

Marie-Ange Véganzonès-Varoudakis

CNRS Researcher, École d'économie - Cerdi, Université Clermont Auvergne - CNRS,

Clermont-Ferrand, France.

E-mail: veganzones@aol.com

Corresponding author: Marie-Ange Véganzonès-Varoudakis

This work was supported by the LABEX IDGM+ (ANR-10-LABX-14-01) within the program "Investissements d'Avenir" operated by the French National Research Agency (ANR).

Études et Documents are available online at: http://www.cerdi.org/ed

Director of Publication: Grégoire Rota-Graziosi

Editor: Catherine Araujo Bonjean

Publisher: Mariannick Cornec

ISSN: $2114-7957$

\section{Disclaimer:}

Études et Documents is a working papers series. Working Papers are not refereed, they constitute research in progress. Responsibility for the contents and opinions expressed in the working papers rests solely with the authors. Comments and suggestions are welcome and should be addressed to the authors. 


\begin{abstract}
Drawing on the World Bank Enterprise Surveys (WBES), we revisit the link between investment climate and firm productive performance for a panel of enterprises surveyed twice in 70 developing countries and 11 manufacturing industries. We take advantage of the surveys done at different times in an increasing number of economies, to tackle the endogeneity issue which has been seen as a problem in previous studies. We also use pertinent econometric techniques to address other biases inherent in the data, in particular measurement errors, missing observations, and multicollinearity. Our results reinforce previous findings by validating, with a larger than usual sample of countries and industries, the importance of a larger set of environment variables. We show that infrastructure quality (Infra), information and communication technologies (ICT), skills and experience of the labor force $(H)$, cost of and access to financing (Fin), security and political stability (CrimePol), competition (Comp) and government relation (Gov) contribute to firms' and countries' different performances. The empirical analysis also illustrates that firms which chose an outward orientation have higher productivity levels. Nevertheless, outward oriented enterprises are, at the same time, more sensitive to investment climate limitations. These findings have important policy implications by showing which dimensions of the business environment, in which industry, could help manufacturing firms to be more competitive in the present context of increasing globalization.
\end{abstract}

\title{
Keywords
}

Investment climate, Outward orientation, Manufacturing, Total factor productivity, Firm survey data.

\section{JEL Codes}

D24, O12, O14, L21, C52. 


\section{1- Introduction}

Manufacturing is traditionally considered as an environment with rapid growth and productivity gains (Kaldor, 1966; Murphy et al, 1989). Productivity in manufacturing is thus important for developing countries to catch up and gain international competitiveness. Understanding the factors that affect industrial performance presents important policy implication for developing economies which face the increasing pressure of globalization.

In the literature, the importance of productivity is generally highlighted as explaining growth differences between countries (Howitt, 2000). Improving productivity in manufacturing, in particular, is recognized as an effective way of enhancing performance and catching up with other better performers (widely known as "the convergence hypothesis"). The central role of manufacturing in the context of rapid growth has also been debated in relation to the surge of the service sector. Some authors have argued that nontraditional ICT-intensive services, which are characterized by a growing tradability, increasing technological sophistication, and low transport costs, are at the forefront of a third industrial revolution (Ghani, 2010). Others, such as Lin (2012), Aghion (2012), and Stiglitz et al (2013) still think that manufacturing remains the only realistic path towards sustained growth for the low-income, low-skilled, and labor-abundant countries of the developing world.

Developments in the economic literature have emphasized the importance of a business-friendly investment climate for robust economic performance (World Bank, 2004). At the macroeconomic level, various empirical studies have used cross-country analysis to highlight the critical role of good governance and institutions (Acemoglu et al, 2001; Engerman and Sokoloff, 2002). More recently, the emergence of enterprise survey data has led to a growing literature that evaluates the determinants of firms' performance (Dollar et al, 2005, Pande and Udri, 2005; Aterido et al, 2011) ${ }^{1}$. By adding a micro economic perspective that captures firms' main constraints, this new approach strengthens the empirical literature which may be used to formulate policy recommendations.

The investment climate can be defined as the "policy, institutional, and regulatory environment in which firms operate" (World Bank, 2004). Key factors affecting investment climate include the rule of law, the quality of the judiciary system, the control of corruption, the level and complexity of taxation and regulation, the quality of infrastructure, the quality of the labor force, the cost and availability of financing, the security and the political stability. Many of these dimensions have been found to be correlated with firms' productivity, investment, and growth ${ }^{2}$. A main hypothesis in the literature is that a good investment climate facilitates the functioning of markets and reduces the transaction risks and costs associated with investing in, starting, operating, and closing down a business. It can also create new opportunities (for example through trade or access to technology) and put competitive pressures on firms. The World Bank (2004) reports as well that a better business environment contributes to the effective delivery of the public goods necessary for productive business (World Bank, 2004; Pande and Udry, 2005; Straub, 2011).

\footnotetext{
${ }^{1}$ See Dethier et al (2008) for a review of the literature.

${ }^{2}$ Bastos and Nasir (2004); Escribano and Guash (2005); Dollar et al (2005), Aterido and Hallward (2007); Aterido et al (2011).
} 
In the literature, firms' outward orientation is a well-accepted key source of productive performance (Balassa, 1978 and 1988; Barro, 1997; Frankel and Romer, 1999). Foreign exposure is seen as presenting increased competition for domestic and exporting firms, encouraging them to invest and be more productive. Additionally, access to foreign capital goods is a source of productivity by technology transfer from advanced countries (Goldberg et al, 2009 and 2010; Topalova and Khandelwal, 2011). This channel is particularly important for developing economies, where new technology is relatively scarce, resources are limited, and firms depend on high-quality imported inputs. In addition to encouraging investment in more productive technologies and organization, international competition is a source of learning as world markets expose firms to more advanced knowledge and technology. Big markets lead also to economies of scale (Coe and Helpman, 1995; Bernard and Jensen, 2004).

The World Bank Enterprise Surveys (WBES) collect data on firms' inputs, outputs and characteristics, as well as on various aspects of their business environment. The WBES provide both subjective evaluations of obstacles to firms' operations, and more objective information on topics such as infrastructure, human capacity, finance, innovation, foreign exposure, competition, crime and government relation. These standardized surveys of large and random samples of firms which reflect the distribution of firms by country, allow the comparison of firm productive performance by sectors and across countries. The WBES also provide information to estimate the impact of the business environment on firms' performance. In a context of increasing pressure from globalization, the WBES can be useful tools for identifying the key obstacles to competitiveness and growth in developing countries. As such, they can inform the design of policy reforms. The objective of this paper is to accelerate progress in that direction.

Drawing on the WBES, this paper analyzes the relationship between the investment climate and firmlevel performance for 11 manufacturing industries in 70 developing economies (see Annex-1 for the list of countries). We first propose a measure of firm performance by using the Total Factor Productivity (TFP) approach. Although a number of studies have recently analyzed the impact of the investment climate on firms' performance, this paper makes a comparison using a much bigger sample of firms, sectors, and countries than traditionally. Another contribution of our research is to go a step beyond what has been done previously, by including the time dimension of the data to tackle the endogeneity issue seen in previous empirical studies. For an increasing number of countries, a sub-sample of firms has been surveyed at different points in time, which makes data available on a panel form, for a substantial number of firms, sectors, and countries. This new time dimension allows the use of more pertinent econometric techniques in this study to check the robustness of previous findings.

Another new facet of our work consists of addressing other constraints of the data, which have led to doubt being cast on the conclusions of previous studies (and on the policy recommendation attached to them). This is the case for the perceived unreliability of firms' answers. It is particularly true for the subjective questions, for which entrepreneurs may have different perceptions, especially when in different countries / regions. Firms may also be tempted to attribute their inefficiencies to external factors. To tackle this issue, we use several methodologies. Following Dollar et al (2005), we first replace each answer by the country-region-size average of the observed variable. We also go a step further by building several prediction models which are used to forecast the firm's answer to the 
survey's questions (considered in that case as exogenous). This process, which helps to address at the same time measurement errors and endogeneity issues, has rarely been used in the literature, especially in the systematic and extended way that we use it in this research (Chaffai et al. 2011 ; Souillard, 2016). .

Another contribution to the literature in this paper relates to the treatment of the investment climate variables. Instead of arbitrarily considering a few indicators, like in most empirical studies, we summarize the information in a limited number of aggregated variables using the Principal Component Analysis (PCA) methodology. The advantage of this approach is that it takes into account more dimensions of the business environment, without encountering problems of multicollinearity when estimating its impact on firm performance (Mitra et al., 2002). In line with the literature, we define 7 composite indicators: infrastructure quality (Infra), ICT availability (ICT), human capacity $(H)$, financing ability (Fin), government relations (Gov), security and political stability (CrimePol), and competition (Comp). Most of these indicators are found to be significantly linked to firm-level TFP. This constitutes an interesting outcome, due to the larger than usual number of investment climate factors validated by the data. These results are robust to the treatment of measurement errors and of endogeneity through the use of various techniques (country-region-size averages of variables, predictions of firm-level observations, and IV estimators). They were obtained using the one-step procedure, which produces less biased coefficients by allowing the simultaneous estimation of both production technology and the factors contributing to firms' TFP.

Finally, special attention is paid to the productive role of the firm's outward orientation in increasing competitive pressure, knowledge spillover and technology adoption from more advanced economies. Firms' foreign exposure is evaluated using several indicators: export status $(X)$, foreign presence in firm capital (ForeingK), quality certification (Cert), and the use of licenses from foreign companies (Lic). All these dimensions are found to positively influence firm productive performance in most manufacturing industries

The paper is organized as follows: In the second section, we present the World Bank Enterprises Surveys (WBES). We describe the data limitations, and explain how we deal with this issue. The third section highlights methodological aspects linked to TFP, our performance indicator. Section four compares average firm-level TFP by industry across countries. Based on the literature, section five introduces the investment climate composite indicators and relates them to firm performance. In the sixth section, we investigate the relationship between firm-level TFP and the variables reflecting firm outward orientation and business environment. The robustness of our results is tested by considering various models and specifications developed to correct the bias linked to the data. The last section concludes with our main findings and their policy implications.

\section{2 - The World Bank Enterprise Surveys (WBES): Data limitations}

The World Bank Enterprise Surveys (WBES) collect data on firm-level inputs, outputs and characteristics, as well as on a large variety of quantitative and qualitative (perception-based) indicators of the business environment. The data are classified in several broad categories: (a) control information; (b) general information; (c) infrastructure and public services; (d) sales and supplies; (e) degree of competition; (f) capacity; (g) land and permits; (h) innovation; (i) crime; (j) business- 
government relation; (k) finance; (l) labor; (m) business environment (summary); (n) performance (see http://www.enterprisesurveys.org/data).

In building the database, we tried to incorporate as much information as possible. We included in our sample the 70 countries for which a sub sample of enterprises have been surveyed at least twice. These countries are in the 5 main regions of the developing world ${ }^{3}$ (List of countries in Annex 1).

To estimate firm-level productivity, we initially considered a population of almost 8,000 firms $(15,764$ observations), from 13 manufacturing industries. This initial sample had to be reduced due to various data limitations. Calculation of productive performance requires information on at least 4 variables: (1) production, (2) intermediate consumption, (3) labor, (4) capital. For some enterprises, part of this information was difficult to get. This is particularly the case for capital. For others, the answers showed clear inconsistencies. Enterprises were eliminated from the sample when productivity and/or production factors were inexistent or judged to be questionable. ${ }^{4}$ In addition, some industries had to be merged, due to an insufficient number of observations. In total, approximately 4,000 enterprises (7,900 observations) grouped into 11 industrial sectors were used for the estimations of the production functions and for the TFP calculations. ${ }^{5}$

Like production and production factors, the investment climate variables are also subject to missing observations and measurement errors. Once outliers and missing variables were removed from the sample, approximately 5,500 observations (around 3,000 enterprises) were left to estimate the factors of productivity (see estimation in section 6).

In addition to missing observations and measurement errors, another important question relates to the endogeneity linked to the qualitative nature of most investment climate variables. This is particularly true for perception-based variables for which firms are asked to position their answer on a given scale. ${ }^{6}$ The perception of the scale may be different across firms, industries, regions and countries. Besides, when answering the questions about their environment, firms may be influenced by the perception they have of their own productivity and attribute their inefficiencies to external factors. Also, highperforming firms may be proactive in reducing their investment climate constraints, for example by working with the authorities to limit inspections, or secure more reliable power supplies.

In the empirical part, we assume this endogeneity exists and use appropriate estimation techniques to better quantify the impact of investment climate variables on firm productive performance. Following Dollar et al (2005), we first make the assumption that firms in the same size category, in the same region, and in the same country, experience a similar business environment and have a similar perception of it. This leads to the measurement of investment climate variables as country-region-size

\footnotetext{
${ }^{3}$ Sub-Saharan Africa $(A F R)$, East Asia $(E A)$, South Asia $(S A)$, East Europe and Central Asia (ECA), Middle East and North Africa (MENA), Latin America (LA),

${ }^{4}$ Some inconsistencies were noted, for example when the hypothesis of constant returns to scale in TFP calculations led to a negative contribution of capital, or when the residual of estimation of the production function was not in line with the standard deviations of the regressions and influenced too much the estimation of coefficients.

${ }^{5}$ Food \&Tobacco; Textile; Garment; Leather; Wood \& Furniture; Plastic \& Rubber; Chemicals \& Petroleum; Non-Metallic $\&$ Basic Metals; Metal Products; Machinery; Transport.

${ }^{6}$ In the case of obstacles to operation for example, firms are asked to quantify their constraints on a scale from none to very severe (0 to 4$)$
} 
averages of firm-level observations ${ }^{7}$. Although we cannot say that this process totally prevents endogeneity, it has the advantage of mitigating measurement errors and the effect of missing observations. If we only keep firms with no missing information, we end up with a smaller sample.

We then apply different models to predict firms' answers to the surveys' questions, and address endogeneity in a better way. The predictions were made as linear combinations of selected exogenous variables, as well as based on probit, logit, or multinomial specifications (or a combination of them). More details on models and variables are given in section 6.2.3. These predictions were used as an alternative to firms' answers when explaining firm-level performance (see sections 5.7, 6.2.3 and 6.2.4). This has also the advantage of correcting for measurement errors.

Finally, we take advantage of the time dimension of the data to address endogeineity in another way. When explaining firm performance, we use the lag value of the business environment variables, as instruments of the contemporaneous ones (see section 6.2.4 for the equations used and the results of the estimations). We also combine this technique with previous predictions by replacing this lag value by its lag prediction in order to correct, at the same time, for measurement errors.

Exchange rate constitutes another source of uncertainty which may lead to over- or under-evaluation of firm productivity. Production and production factors were converted into US dollars for comparability of TFP calculation across countries. Several exchange rates can be used to calculate and compare firmlevel productivity. In this study, we used the current market rate in US dollars, which is the same rate that firms use for their financial calculations

\section{3 - Firm-Level Productive Performance: Methodological Aspects}

Firms' productive performance, which can be evaluated using various indicators of productivity, is generally understood to be the ability of a firm to transform inputs into outputs (OECD, 2001). Easyto-calculate measures include labor productivity $(L P)$, or partial productivity calculated as the ratio of the firm's output to any factor of production (e.g. capital). When all production factors are taken together, productivity can be measured by non-parametric total factor productivity (TFP) (also called the Solow residual), which is calculated as the residual of a given production function, or parametric TFP and technical efficiency (TE), calculated as the residual of an estimated production function/frontier. These two measures have the advantage that firms can be bench-marked using a standard measure of performance, which allows direct comparisons between firms and countries.

In a dynamic analysis, TFP growth can be the result of a technical change $(T P)$ or the consequence of a technical efficiency improvement (TE). Technical change represents an upward shift of the production frontier, while technical efficiency improvement is a move within the feasible production range towards the frontier (technology remaining unchanged). In a static framework, the 2 concepts, TE and TFP level, can be used interchangeably. Technical efficiency is no more than a relative productivity level, all sample firms being benchmarked against those which operate at the frontier, (i.e. those firms which represent the best "practice"). Our objective in this paper is to determine how firms perform

\footnotetext{
${ }^{7}$ We make sure we have a sufficient number of observations by region and sector. If not, we substitute country-size averages to countryregion-size averages.
} 
relative to others. Because the 2 concepts are equivalent, we chose to focus on TFP due to its simplicity. 8

For calculating TFP, the Cobb-Douglas technology is the one which is most often used, because the elasticity of production to inputs is easy to observe and interpret. The model we estimate in the next section can be written as:

$\log \left(Y_{\mathrm{i}, \mathrm{j} .}\right)=\mathrm{c}+\alpha \log \left(K_{\mathrm{i}, \mathrm{j} .}\right)+\beta \log \left(L_{\mathrm{i}, \mathrm{j} .}\right)+\varphi_{1}$ Country $_{i, j, j}+\varphi_{2} \operatorname{Reg}_{i, j, j}+\varphi_{3}$ Year $_{i, j, j}+v_{i, \mathrm{j} .}$

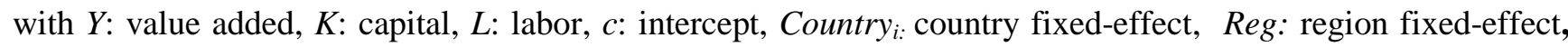
Year: year of survey, $\alpha / \beta / \varphi_{1 \text { to } 3}$ : parameters to be estimated, $v_{i, \mathrm{j} \text {. }}$ error term and $\mathrm{i} / \mathrm{j}$ : observation/country index, respectively.

The country and region dummy variables aim to capture the effect of country and region specific factors, such as natural resources, national and regional institutions, trade policy, macro or political instability. There are good reasons to think that firms' value added may vary across countries and regions for reasons other than production conditions. Furthermore, taking into consideration these fixed-effects, and the year of survey results in a reduction of the omitted variable bias when estimating the elasticities of capital and labor. This in turn contributes to a better calculation of TFP.

Firm TFP is calculated as the residual of the estimated production function. The equation is as follows:

$\operatorname{TFP}_{\mathrm{i} . \mathrm{j} .}=\log \left(Y_{\mathrm{i} . \mathrm{j} .}\right)-\alpha \log \left(K_{\mathrm{i}, \mathrm{j} .}\right)-\beta \log \left(L_{\mathrm{i}, \mathrm{j} .}\right)$

These calculations will be presented in the next section, by industry and by country.

A complement to this analysis consists of determining the reasons why some firms are less productive than others. Factors that may influence TFP can be tested in different ways. One method is to estimate the production functions as in (1) and then to regress the TFP obtained as in (2), on a vector of explanatory factors. This "two-step" procedure has several shortcomings, including a question of identification. When any of the production function inputs (X) is influenced by common causes affecting TFP, there is a simultaneity problem due to the omission of explanatory variables in the first stage estimation (Bastos and Nasir, 2004). In addition, despite the fact that the country (region) fixedeffects are aimed at reducing the omitted variable bias, it may not be sufficient. The estimated elasticities of labor and capital may still be biased, and so TFP as well. The most recent literature proposes to simultaneously estimate all the parameters in "one-step". In this case, the extended production model can be rewritten as:

$\ln \left(Y_{i, j}\right)=\alpha \ln \left(L_{i, j}\right)+\beta \ln \left(K_{i, j .}\right)+\gamma C_{i, j}+\delta Z_{i, j}+c+\varphi_{1} \operatorname{Reg}_{i, j, j}+\varphi_{2} Y_{e a r_{i, j}}+v_{i, j}$

\footnotetext{
${ }^{8}$ In this paper, we only refer to productivity levels because of the limited time dimension of the production factors. Our analysis focuses on comparisons of firm-level productivity across enterprises, industries, and countries. Measuring productivity level, although more restrictive than measuring growth rates (which requires, for instance, specific functional forms of the production function), is less demanding in terms of data quality requirements. It permits, in particular, the use of unbalanced panels with short time dimensions, measurement errors, or constant value of $I C$ variables (see Escribano and Guasch, 2005).
} 
with $Y$ :value added, $K$ : capital, $L$ : labor, $C$ : vector of control variables, $Z$ : vector of investment climate indicators, Reg: region fixed-effects, Year: year of survey, $c$ : intercept, $v$ : error term, $\alpha \beta, \gamma, \delta, \varphi_{1,2}:$ parameters to be estimated, $i / j$ : observation/country index, respectively.

When estimating the factors of productivity, country fixed-effects are not included in the equation. As highlighted in the literature, they could "wash away" the role of some of the explanatory factors of TFP (the investment climate variables in particular). It is this model that we estimate in section 6.

\section{4 - Calculating Firm-Level Total Factor Productivity (TFP)}

Firm-level production functions are estimated as in equation (1). This step is necessary to first relate total factor productivity (TFP) across firms and countries. It is also useful to evaluate the estimation bias when compared to the results of the one step procedure (as in equation 3). At this stage, we explain firm value added $\left(Y_{\mathrm{i}}\right)$ by firm capital $\left(K_{\mathrm{i}}\right)$ and firm labor $\left(L_{\mathrm{i}}\right)$. Country, region and year of survey fixedeffects are also introduced in order to minimize the omitted variable bias. Value added is calculated as the difference between firm total sales and total purchase of raw material, excluding fuel. ${ }^{9}$ All values are taken in current US dollars. We make the hypothesis that firms are price takers, and purchase raw materials at world price. This appears to be an acceptable assumption for manufacturing industry which is exposed to international competition. In this case, the prices in US dollars of production and intermediary consumptions are comparable across countries. $K_{\mathrm{i}}$ is the firm gross value of property, plant, and equipment, and $L_{\mathrm{i}}$ is the number of firm full time permanent workers. Outliers have been excluded from the database as explained in section 2 (see Annex 3 Table-A2 for the statistics of the production function variables).

Firm-level production functions are estimated at the sector level, on unbalanced panels with a range of 1987 observations for the Food industry, to 558 observations for Transport, using the reasonable assumption that an industry-based technology leads to more homogeneous production functions, and makes it easier to attribute the residual to differences in productivity. Differences in the coefficients of factors across branches justify this choice, as shown by our results (see Table 1 below).

The value of these coefficients is however not always in line with what we know about the technology of production. In heavy industry, elasticity of capital compared to elasticity of labor can be quite low (especially in Transport which has a ratio of 0.13 versus 0.32 in Rubber \& Plastics), compared to light industry ( 0.21 in Leather to 0.26 in Food). Elasticities are also more stable in light industries than in heavy industries. An explanation could be that the lower number of observations for the heavy industries than for the light industries, reduces the robustness of the estimations. Another explanation could be a lower quality of data, possibly due to the fact that capital is usually more difficult to evaluate than labor. This could lead to more errors in the data for capital in heavy industries than in light industries, which are by definition less capital intensive. In addition, constant returns to scale are not validated by the data (with increasing returns to scale in all cases, see Table 1). Furthermore, the findings for Electronics were not satisfactory, and knowing that the results will not get better in the following sections, we removed the sector from the sample.

\footnotetext{
${ }^{9}$ This is the proxy usually used in the literature. Because of the absence of time dimension on an annual basis; it is not possible to evaluate the stock variation that would allow calculation of the real intermediate consumption during the year.
} 
Table 1- First-Step Production Function: Estimation Results by Sector

(Dependant Variable: Log of Firm Value-Added)

\begin{tabular}{|c|c|c|c|c|c|c|c|c|c|c|c|c|}
\hline Sector & Food & Textile & Garment & Leather & $\begin{array}{c}\text { Wood } \\
\text { Furniture } \\
\end{array}$ & $\begin{array}{l}\text { Rubber } \\
\text { Plastic } \\
\end{array}$ & $\begin{array}{l}\text { Chemicals } \\
\text { Petroleum } \\
\end{array}$ & $\begin{array}{c}\text { Non Metal } \\
\text { Basic Metal }\end{array}$ & $\begin{array}{c}\text { Metal } \\
\text { Product }\end{array}$ & Machinery & Transport & $\begin{array}{c}\text { Manuf } \\
\text { Total }\end{array}$ \\
\hline \multirow[t]{2}{*}{$\mathbf{L}$} & $0.925 * * *$ & $0.929 * * *$ & $0.899 * * *$ & $1.034 * * *$ & $1.067 * * *$ & $0.934 * * *$ & $0.987 * * *$ & $0.978 * * *$ & $1.020 * * *$ & $1.045^{* * * *}$ & $1.158 * * *$ & $0.882 * * *$ \\
\hline & (26.58) & $(21.51)$ & (33.01) & (21.10) & (21.35) & (17.72) & (27.04) & (22.95) & $(22.51)$ & (26.08) & (24.94) & $(55.03)$ \\
\hline \multirow[t]{2}{*}{$\mathbf{K}$} & $0.237 * * *$ & $0.237 * * *$ & $0.233 * * *$ & $0.216 * * *$ & $0.281 * * *$ & $0.298 * * *$ & $0.214 * * *$ & $0.231 * * *$ & $0.228 * * *$ & $0.195 * * *$ & $0.151 * * *$ & $0.260 * * *$ \\
\hline & (11.85) & $(9.90)$ & (13.32) & $(7.39)$ & (10.00) & $(9.67)$ & (11.78) & $(9.79)$ & $(8.99)$ & $(6.44)$ & $(6.13)$ & $(25.51)$ \\
\hline \multirow[t]{2}{*}{ Year } & $0.031 *$ & 0.026 & $0.04 * * *$ & 0.03, & $-0.023^{*}$ & $-0.056 * *$ & $0.035^{* *}$ & $0.073 * * *$ & $0.029^{\prime}$ & $0.048 * *$ & $0.063 * * *$ & $0.032 * * *$ \\
\hline & $(2.41)$ & (1.64) & $(3.77)$ & $(1.76)$ & $(-2.11)$ & $(-3.27)$ & $(2.71)$ & $(4.52)$ & $(1.78)$ & $(3.04)$ & $(4.06)$ & $(5.67)$ \\
\hline \multirow[t]{2}{*}{ Intercept } & $-55.9^{*}$ & -45.6 & $-74.5^{* * *}$ & -53.6 & $53.2^{*}$ & $117.4 * * *$ & $-60.8^{*}$ & $-140.6^{* * *}$ & -51.1 & $-93.1 * *$ & $-119.9 * * *$ & $-57.9 * * *$ \\
\hline & $(-2.16)$ & $(-1.45)$ & & & $(2.39)$ & & & & $(-1.55)$ & $(-2.92)$ & $(-3.83)$ & \\
\hline ProbaCRScale & 0 & 0 & 0 & 0 & 0 & 0 & 0 & 0 & 0 & 0 & 0 & 0 \\
\hline 'e K/ e L & 0,26 & 0,26 & 0,26 & 0,21 & 0,26 & 0,32 & 0,22 & 0,24 & 0,22 & 0,19 & 0,13 & 0,29 \\
\hline $\mathbf{R}^{2}$ & 0.77 & 0.79 & 0.83 & 0.84 & 0.78 & 0.73 & 0.81 & 0.82 & 0.84 & 0.81 & 0.86 & 0.77 \\
\hline Observations & 1987 & 1112 & 1714 & 657 & 1026 & 769 & 1192 & 924 & 887 & 825 & 558 & 7902 \\
\hline
\end{tabular}

Source. Authors' estimations.

Note K: capital (in $\log$ ); L: labor (in $\log$ ); Year: year of survey. All regressions contain country and region fixed-effects. The regression for total manufacturing contains in addition sector fixed-effect. Production functions are estimated by a pool OLS. Heteroskedasticity-robust t-students are reported in parentheses. $* * *, * *, *$, and ' denote significance at the $0.1 \%, 1 \%, 5 \%$, and $10 \%$ levels, respectively. e K: elasticity of capital ; e L: elasticity of labor; CR: constant returns.

If we consider the limitations of this first specification (in regard to the omitted variable bias) the results are not a surprise. As mentioned in the previous section, it looks like the country, region, year fixed-effects are insufficient to capture the missing determinants common to all firms. This question will be answered in section 6 , when estimating the production functions extended to the factors of productivity. For now, our results will only be used to calculate the country average firm-level productivity by sector, to compare firms' performance across countries.

Table-2 displays the country average firm-level total factor productivity (TFP) by sector, as calculated from the estimated production functions (equation 2 and Table 1). For a given sector, country average firm TFP is expressed in percent, relative to the country where firms show the highest performances (for which the value is 100 in the table).

The analysis reveals a relatively stable ranking of countries across industries. Firms in most Latin American economies perform, on average and in several industries, at the highest levels of TFP. This is true for Argentina, Chile, Uruguay and, to a lower extent, Brazil, Colombia and Mexico. This result is consistent with these economies' higher level of development than most of the other economies in the sample.

In the African sub-continent, South African firms appear to be the most productive, in most sectors and at a level comparable to the best performing firms in Latin America. This result does not come as a surprise either, and confirms some earlier findings on the subject (see Kinda et al, 2014). South Africa, however, is an exception, and no other African firms/ countries in our sample appear able to compete at the international level. 
In Eastern Europe and Central Asia, like in most of African countries, the country sample size is small in some sectors. This makes the comparison with Latin America difficult because the number of observations for the Latin American countries is greater (this means the estimation results may be less biased). Nevertheless, the leader of Eastern Europe and Central Asia appears to be Turkey, with an average level of firm performance comparable to the one of the best performers in Latin America. This result also fits with intuition if we think about Turkey's development level, although we should remain cautious because, as mentioned above, there is also less information for Turkish firms.

Table-2- Country Average of Firm-Level Total Factor Productivity by Industry (in $\%$ of country with the most productive firms)

\begin{tabular}{|c|c|c|c|c|c|c|c|c|c|c|c|}
\hline Country & Manuf & Food & Textile & Garment & Leather & $\begin{array}{c}\text { Wood } \\
\text { Furniture }\end{array}$ & $\begin{array}{l}\text { Chemicals } \\
\text { Petroleum }\end{array}$ & $\begin{array}{l}\text { Rubber } \\
\text { Plastic }\end{array}$ & $\begin{array}{l}\text { Non-Metal } \\
\text { Basic Metal }\end{array}$ & $\begin{array}{c}\text { Metal } \\
\text { Products }\end{array}$ & Machinery \\
\hline Angola & 86 & 80 & & 81 & & 90 & & & 95 & 85 & \\
\hline Botswana & 84 & 79 & 84 & 71 & & 95 & & & 93 & 81 & \\
\hline Ethiopia & 78 & 80 & 83 & 72 & 75 & 80 & 75 & 74 & 81 & 80 & \\
\hline Kenya & 80 & 80 & 78 & & & & & & & & \\
\hline Mali & 78 & 78 & & 74 & & & & & & 75 & \\
\hline Nigeria & 53 & 38 & & 64 & & 45 & & & 27 & & \\
\hline Senegal & 83 & 85 & & 78 & 81 & 80 & 83 & & 80 & 78 & \\
\hline South Africa & 98 & 91 & & 99 & & 100 & 96 & 97 & 100 & 92 & 100 \\
\hline Tanzania & 80 & 76 & & 76 & & 97 & 80 & 84 & 81 & 75 & \\
\hline Uganda & 75 & 71 & & & & 78 & 78 & & 79 & 72 & \\
\hline Indonesia & 79 & 72 & 79 & 78 & & 79 & 78 & 78 & 75 & 81 & \\
\hline Mongolia & 78 & 78 & & & & & & & 69 & & \\
\hline Philippines & 86 & 82 & & 77 & & 86 & 86 & 93 & 82 & 81 & \\
\hline Timor & 80 & 71 & & & & 87 & & & & & \\
\hline Vietnam & 83 & 85 & & 77 & & 80 & 86 & 90 & 82 & 82 & 82 \\
\hline Belarus & 82 & & & 75 & & 84 & & & & & \\
\hline $\begin{array}{l}\text { Macedonia, } \\
\text { FYR }\end{array}$ & 89 & 90 & 84 & 82 & 80 & 93 & & & & 93 & \\
\hline Moldova & 84 & 81 & & 75 & & & & & & 96 & \\
\hline Turkey & 100 & 100 & 97 & 100 & & & 99 & & 98 & & \\
\hline Ukraine & 80 & 84 & & 75 & & & & & 76 & & 86 \\
\hline Uzbekistan & 77 & 76 & 82 & & & & 68 & & 68 & & \\
\hline Russian & 92 & 87 & & 86 & & & 91 & & & 92 & 95 \\
\hline Argentina & 98 & 94 & 100 & 97 & 100 & & 95 & 97 & & 97 & 100 \\
\hline Bolivia & 86 & 82 & 86 & 83 & & & 88 & & & & \\
\hline Brazil & 88 & 66 & 86 & 88 & 92 & 95 & 100 & & & 80 & 97 \\
\hline Colombia & 91 & 88 & 91 & 91 & 99 & & 91 & 97 & & 88 & \\
\hline Chile & 99 & 94 & 99 & 96 & 63 & & 61 & 100 & 86 & 100 & 78 \\
\hline Ecuador & 91 & 89 & & 79 & & & 90 & 96 & & 90 & \\
\hline Guatemala & 86 & 84 & 89 & 82 & & & & & & & \\
\hline Mexico & 91 & 86 & 86 & 91 & & & 87 & & 84 & 85 & 96 \\
\hline Paraguay & 89 & 88 & & 95 & & & 85 & 93 & 80 & & \\
\hline Peru & 90 & 92 & 89 & 88 & & & 90 & & & & \\
\hline Uruguay & 96 & 94 & 91 & 90 & & & 95 & 97 & & & \\
\hline Egypt & 80 & 75 & 76 & 82 & & 77 & 83 & 84 & 76 & 72 & 85 \\
\hline Morocco & 87 & 90 & 89 & 78 & 92 & & 92 & & & 90 & \\
\hline Yemen & 76 & 80 & & 76 & & 64 & & & 70 & & \\
\hline Bangladesh & 74 & 68 & 75 & 76 & 82 & & 70 & & & & 75 \\
\hline Nepal & 78 & 82 & 68 & & & 78 & 84 & 76 & 77 & 72 & \\
\hline Pakistan & 85 & 89 & 81 & 76 & 82 & 83 & 77 & & 78 & 89 & \\
\hline
\end{tabular}

Source : Authors' calculations

Note: Country averages of firm TFP are expressed in percent, relative to the country where firms show the highest performance (for which the country average is 100).

As for the rest of the sample, firm productivity looks quite low in most of our Middle-Eastern and North African (MENA), South-Asian (SA) and East-Asian (EA) economies, with the exception of 
Morocco, whose firms perform quite well in some sectors (Food, Leather, Chemicals), at a level quite close to that of the best performing firms. This result also confirms previous findings on the subject (Kinda et al, 2014). It is necessary to remember, however, that for these 3 regions, the number of countries represented in the sample is small. In addition, for South East Asia (SEA) and MENA, the wealthier countries are not represented in the sample.

\section{5 - Measuring Investment Climate}

In the surveys, there are multiple indicators covering a similar theme, and their correlation is high. The solution usually adopted in the literature consists of restricting the analysis to a limited number of indicators. This solution has the disadvantage of accepting a potential omitted-variable bias. It also poses the question of whether or not the selected variables provide a representative description of the investment climate. The solution of using a composite indicator has the interest of obtaining more accurate estimates, in addition to including more dimensions of the business environment. Most of the empirical literature relies on individual variables to capture different dimensions of the investment climate, and few previous authors have shown interest in aggregating variables. ${ }^{10}$

Aggregation is particularly suitable in our case, since we aim to incorporate an as large as possible set of variables not typically used in the literature, to determine which investment climate dimensions are most detrimental to firm performance. Although different methods of aggregation exist, the Principal Component Analysis (PCA) aggregates basic indicators in a more rigorous way than a subjective scoring system (see for example the rating system elaborated by the ICRG, PRS group).

The Principal Component Analysis (PCA) methodology is a widely-used aggregation technique, designed to linearly transform a set of initial variables into a new set of uncorrelated components, which account for all of the variance in the original variables. Each component corresponds to a virtual axis on which the data are projected. The earlier components explain more of the variance of the series than do the later ones. The number of components is proportional to the number of initial variables that are used in the PCA. Usually, only the first components are retained, because they explain most of the variance in the data-set.

The initial indicators were selected on the basis of being available for the countries of our sample, as well as capturing the different key dimensions of the firm business environment. Another element of choice was to add quantitative indicators to qualitative (perception-based) ones, to get a better picture of the firm investment climate in each industry and country. Based on the literature, we defined 7 categories of firm business environment: infrastructure quality (Infra), information \& communication technology (ICT), human capacity $(H)$, financing ability (Fin), government relations (Gov), security \& political stability (CrimePol) and competition (Comp). ${ }^{11}$ (See Annex 2 and 3 for the list of variables and the statistics for them).

\footnotetext{
${ }^{10}$ See Manly (1994); Mardia et al (1997); Bastos and Nasir (2004).

${ }^{11} 3$ of these indicators (Infra, CrimePol and Gov) are exogenously determined and relate to an external environment in which the State plays a crucial role. 3 others (H, Fin, ICT) are not pure external factors. They are partly determined by firms' decisions but prove difficult to change over the short run. The variables which do not relate to the investment climate
} 


\subsection{Infrastructure Quality and Use of ICT}

The infrastructure indicator (Infra) is composed of 4 variables: (a) Does the firm experience power shortages? (b) Does the firm own or share a generator? Obstacle ${ }^{12}$ for the operation of the enterprise caused by deficiencies in $(\boldsymbol{c})$ electricity and $(\boldsymbol{d})$ transport.

The ICT indicator is composed of 3 variables: Does the Enterprise have access to $(\boldsymbol{a})$ E-mail or $(\boldsymbol{b})$ Internet in its interaction with clients and suppliers? (c) Obstacle for the operation of the enterprise caused by deficiencies in Telecommunications.

In developing countries, infrastructure deficiencies constitute an important constraint to private sector development (World Bank, 1994). More recently, electricity has emerged as a particularly severe problem in poor countries (Carlin et al, 2006; Gelb et al, 2007). Poor infrastructure, by increasing operating costs, is seen as a burden for firms' operations and performance, thus affecting their competitiveness. As a complementary factor to other production inputs, infrastructure stimulates in addition private productivity by raising investment in new and more productive equipment (Blejer and Kahn, 1984 ; Aschauer, 1989 ; Murphy et al, 1989 ; Barro, 1990 ; Argimon et al, 1997). Infrastructure is also at the origin of externalities across firms, industries, and regions ${ }^{13}$. Regression analysis confirms that infrastructure deficiencies are harmful to firms' performance (Escribano and Guash, 2005; Dollar et al, 2005; Bastos and Nasir, 2004). Papers that do not validate this effect are in the minority, and have generally very specific samples or methodological limitations (Commander and Svejnar, 2007; Fismann and Svensson, 2007) ${ }^{14}$.

\subsection{Human Capacity}

The human capacity indicator $(H)$ is composed of two variables: (a) number of years of experience of the top manager. $(\boldsymbol{b})$ Training of the firm's employees.

Human capacity constitutes an essential factor of firms' performance. In developing countries, human capital can be scarce (World Bank, 2007 and 2017). This represents a constraint for firm productivity and competitiveness. Because skilled workers are better at dealing with change, a skilled work force is essential for firms to adopt new and more productive technologies (Acemoglu and Shimer, 1999). Also, new technologies generally require significant organizational changes, which are better handled by a skilled workforce and an experienced manager (Bresnahan et al, 2002). In addition, by raising firms' profitability, human capacity stimulates productivity through capital formation and technical progress embodied in new equipment. Human capacity can also give the opportunity to enterprises to expand or enter new markets, which leads to economies of scale and productivity gains. Finally, human capital is at the origin of positive externalities across firms and sectors (Lucas, 1988 ; Psacharopoulos, 1988 ; Mankiw et al, 1992). Empirical evidence of the role of human capital on firmlevel performance is also well established (Bresnahan et al, 2002, and Lima et al, 2004).

are associated with firms' characteristics such ownership, export status, quality certification and licenses from foreign companies.

${ }^{12}$ Firms are asked to position their answer on a scale from $\mathbf{0}$ (no obstacle) to $\mathbf{3}$ (very severe obstacle)

${ }^{13}$ For spatial externalities, see Holtz-Eakin and Schwartz (1995).

${ }^{14}$ For a review of the literature, see Straub (2011). 


\subsection{Financing Ability}

The financing indicator (Fin) is composed of 3 variables: (a) Percentage of inputs purchased on credit. (b) Access to an overdraft facility. (c) Obstacle for the operation of the enterprise caused by the access to Financing

Financing capacity appears to be a major determinant of firms' performance in developing countries. In the literature, access to (and cost of) financing is associated with the ability of firms to finance more investment projects. The financing of investment projects leads to increased productivity through higher capital intensity and technical progress embodied in the new equipment. Financial development also has a positive effect on productivity as a result of a better selection of investment projects and higher technological specialization through diversification of risk. A developed financial system creates more profitable investment opportunities by mobilizing and allocating resources to the projects that will generate the most surplus (Levine, 1997). In most developing countries, financial systems are under-developed, leading to financing cost and access to financing to be reported as sizable constraints by the firms (World Bank, 2004; Carlin et al, 2006). In the empirical literature, access to financing is clearly identified as impeding firms' performance (Carlin et al, 2006; Gelb et al, 2007; Aterino et al, 2011).

\subsection{Government Relation}

The government relations indicator (Gov) is composed of 8 variables: (a) Has the firm been inspected by tax officials? $(\boldsymbol{b})$ Percentage of time spent to deal with government regulations. (c) Has a gift been given when inspected by tax officials? Obstacle for the operation of the enterprise caused by $(d)$ tax rate, $(\boldsymbol{e})$ tax administration, $(\boldsymbol{f})$ labor regulation, $(\boldsymbol{g})$ business licensing and operating permits and $(\boldsymbol{h})$ corruption.

This indicator illustrates the capacity of the government to provide an investment-friendly environment and reliable conditions for the private sector. Corruption is seen as having an adverse effect on firms' productive performances by increasing costs, as well as uncertainties about the timing and effects of the application of government regulations (Tanzi and Davooli, 1997). This fact is well documented, and is often described as one of the major constraints facing enterprises in the developing world (World Bank, 2004; Carlin et al, 2006; Gelb et al, 2007). Taxation and regulations have also an effect on firms' costs and productivity. Government regulation and taxation are needed to protect the general public and to generate revenues to finance the delivery of public services and infrastructure. However, over-regulation and over-taxation deter productive performance by raising business start-up costs and firms' operating costs (World Bank, 2004 and 2016).

Although empirical evidence generally points in the direction of a strong negative effect of corruption on firms' performance, validating in the literature the so called "sand the wheels" hypothesis (Gaviria, 2002 ; Bastos and Nasir, 2004 ; Fismann and Svensson, 2007 ; Aterino et al, 2011 ; Wang and You, 2012 ; Hanousek and Kochanova, 2016), some studies find no relation, or a negative one for some indicators (Escribano and Guash, 2005; Beck et al, 2005 ; Hanousek and Kochanova, 2016). This would support the opposite hypothesis "grease the wheels", or a reverse causality, the most productive firms being 
more subject to various forms of corruption. The same conclusion is reached for regulations, with empirical evidence found both for a negative effect of regulation on firms' performance (see Escribano and Guash, 2005; Beck et al, 2005), and a positive one in some cases (Aterino et al, 2011).

\subsection{Security and Political Stability}

The security and political stability indicator (CrimePol) is composed of 4 variables: $(\boldsymbol{a})$ Is the firms paying to ensure its security? (b) Has the firm experimented losses due to robbery? Obstacle for the operation of the enterprise caused by $(\boldsymbol{c})$ crime and $(\boldsymbol{d})$ political instability.

Crime and insecurity appear to be an increasing issue in many developing countries (World Bank, 2011; Goldberg et al, 2014). In the WBES, firms often describe property crime, such as theft, robbery, vandalism and arson, as an important constraint with direct consequences on their activity level. In several countries, crime-related losses are more than bribery or power outage costs (Amin, 2009). The burden of crime appears to be especially high for small and medium sized enterprises (SMEs), although big enterprises seem to bear the heaviest cost (Islam, 2014).

Crime inflicts a big toll on private sector development. In addition to the direct costs of criminal acts, insecurity has an effect on firms' competitiveness by raising security and operating costs. Crime diverts firms' scarce resources from productive use to payments to security companies (World Bank, 2011). Insecurity further reduces investment and firms' productivity gains by raising uncertainty and the risks associated with the business. Insecurity goes hand in hand with other issues, such as fraud, corruption, and weak institutions, further weakening the already vulnerable business environment in developing economies. As for political instability, by increasing uncertainty and reducing predictability, it raises the cost of doing business and deters risk-adverse entrepreneurs from taking action for profitable opportunities and investment. Various authors have presented empirical evidence that institutions associated with political instability hamper aggregate growth and firm performance (Alesina et al, 1996; Svensson, 1998, Olson et al, 2000). As for insecurity, a growing literature also highlights the detrimental effect of crime on firms' activity and competitiveness (Gaviria, 2002, and BenYishay, 2014),

\subsection{Competition}

The competition indicator (Comp) is composed of 2 variables: (a) Is the enterprise's main market local, national, or international? $(\boldsymbol{b})$ Obstacle for the operation of the enterprise caused by the presence of the informal sector.

In the framework of the neoclassical theory, competition goes hand in hand with economic performance (Aghion and Griffith, 2005). Productivity gains are expected from competitive pressure on domestic and export oriented firms. Competition is a factor which induces investment in more productive technology and organization, in addition to economies of scale and learning effects because big markets expose firms to more advanced knowledge and technology. Competition can also come from the informal sector, which constitutes a big part of developing economies (Schneider et al, 2010). This competition, however, can be considered to be unfair because the informal sector escapes many 
constraints imposed on firms by the government, such as paying taxes on labor or income, and respecting rules and regulations (Schneider and Enste, 2000; La Porta and Shleifer, 2014). The positive

\section{Graph 1: Country Average Firm-Level Investment Climate and TFP}
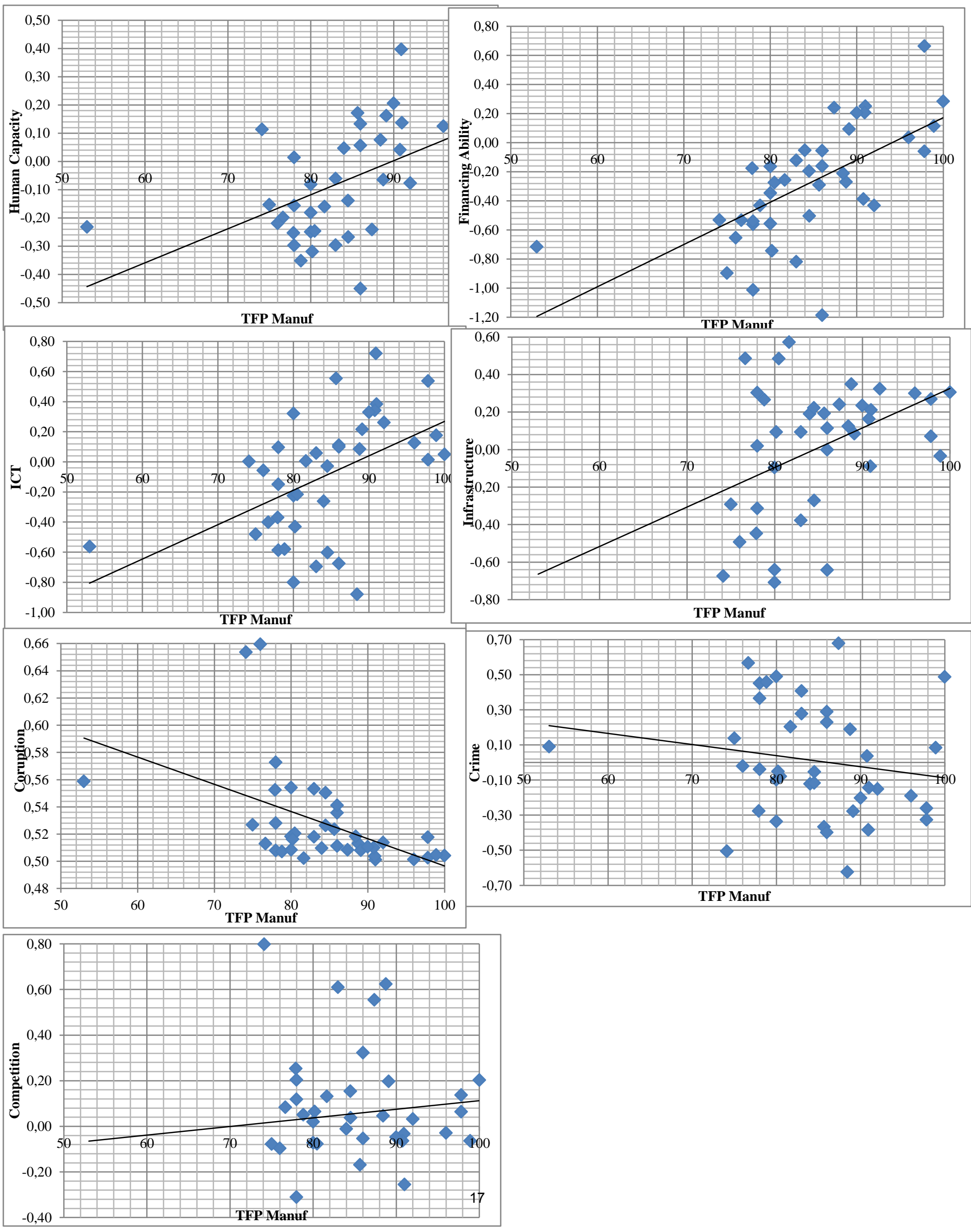
Note: Country averages firms TFP are in percent, relative to the country where firms show the highest performance (see Table 2). For all graphs, investment climate indicators can be read as a capacity. Negative values are due to the aggregation methodology and do not have any economic interpretation. A smaller value means that the corresponding business environment dimension is less favourable in that country than in another one with a higher value of the same indicator. Corruption is a proxy of government relation (Gov). See Annex 2 for the definition of the composite indicators.

impact of competition on firms' performance was validated by Bastos and Nasir (2004) and Commander and Svejnar (2007), and the negative impact of the informal sector by González and Lamanna (2007) and Ospina and Schiffbauer (2010).

\subsection{Calculation of the Aggregated Indicators}

All the aggregated indicators were generated at the sector level, thus defining the specific investment climate of each industry ${ }^{15}$. In total this resulted in 77 indicators ( 7 for each of the 11 sectors). Some initial variables had to be recoded in order to enter the composite indicators with the right sign. Because we made the choice to interpret our investment climate indicators as "capacities" (that is to say participating positively in firms' performance) we had to change the direction of the variables perceived as a constraint or a handicap (e.g. power shortages, security costs, losses from robbery, government inspections, etc, and "obstacle" variables).

Analysis usually treats investment climate as an exogenous determinant of firm productivity. However, as already mentioned in section 3, this is not always the case. We addressed this issue by, first, replacing the initial variables which enter the PCA by their size-region-country average, as in Dollar (2005). This also helps to mitigate measurement errors, as well as increasing the number of observations by including in the sample firms for which information is missing. Then, we substituted the initial variables by their predicted values, as explained in section $2^{16}$. This also has the advantage of mitigating measurement errors. Finally, we replaced the second survey's observations by the first survey's observations, then, by the first survey's predicted value, as in the previous step. Each time, we ended up with different aggregated indicators, that we introduced in turn into our equations for TFP, in order to check the robustness of our results.

As an example, we present the results for the 7 investment climate composite indicators calculated for the whole manufacturing industry from the observed initial variables (first example above). We compare the country average of each firms' indicator to the same country's average firm TFP (see graph 1). As mentioned above, aggregated indicators are interpreted as capacity. Negative values are

\footnotetext{
${ }^{15}$ The principal components of the initial variables were extracted for each aggregated indicator. The 7 composite indicators were then constructed as the weighted sum of a certain number of principal components, depending on the explanatory power of each component. We chose the most significant principal components whose eighen-values were higher than 1 . In this case, we explain around $70 \%$ of the variance of the underlying initial variables. The weight attributed to each principal component corresponds to its relative contribution to the variance of the initial indicators (calculated from the cumulative $\mathrm{R}^{2}$ ). For more details on the aggregation method, see Mitra et al (2002).

${ }^{16}$ Details about the prediction equation are given in section 6.2 .3
} 
due to the aggregation method and do not have any economic interpretation ${ }^{17}$. A smaller value means that the business environment is less favorable than in another country/sector (see footnote 19 for the construction of the composite indicators). These results provide a lot of information, and show that higher firm productivity is on average associated with better business environment.

\section{6 - Explaining Firm-level Total Factor Productivity (TFP)}

In this section, we seek to explain the differences in productivity level across firms and countries (see section 4). The one-step procedure is used to simultaneously estimate the production technology and the factors influencing TFP. This helps to mitigate the missing variables bias (see section 3). Although several factors may explain these differences, the business environment is probably one of them (see section 5). This hypothesis is tested through different specifications aimed at corroborating our findings. To reduce the multicollinearity bias, we first use the investment climate composite indicators derived from the firms' answers to the questions in the surveys (see section 6.2.1). We then substitute for these observed answers, their size-region-country average value, to address the missing observation and error measurement bias, and to mitigate endogeneity issues (see section 6.2.2). To better address these issues, we next substitute for the observed variables their predicted value, using the different models presented in section 5 (see section 6.2.3). As a last correction for endogeneity, we use as instrument of the second survey initial variables, the first survey answers and, as a variant, the first survey predictions (see section 6.2.4).

\subsection{The Empirical Model}

Our empirical model explains firm-level total factor productivity (TFP) by regressing, for each of the 11 branches and also for total manufacturing, the logarithm of the production factors $(K$, capital and $L$, labor), various plant characteristics, as well as the investment climate composite indicators, on the logarithm of the value added $(Y)$, as in the one-step procedure presented in section 3 (equation 3 ). Production variables and investment climate indicators are as defined in sections 4 and 6. Our empirical model uses the same specification for all industries. The equation is as follows:

$\ln \left(Y_{i . j}\right)=\alpha \ln \left(L_{i . j}\right)+\beta \ln \left(K_{i, j}\right)+\gamma_{1}$ age $_{, j,}+\gamma_{2}$ Cert $_{i, j}+\gamma_{3}$ Lic $_{i, j},+\gamma_{4}$ Foreign $_{i . j}+\gamma_{5}$ Export $_{i . j}+\varepsilon_{1}$ Infra $_{i . j}+\varepsilon_{2}$
ICT $_{i . j}+\varepsilon_{3} H_{i, j}+\varepsilon_{4}$ Fin $_{i . j}+\varepsilon_{5}$ Gov $_{i j .}+\varepsilon_{6}$ CrimePol $_{i j .}+\varepsilon_{7}$ Comp $_{i j .}+\varphi_{1}$ Reg $_{i, j . j}+\varphi_{2}$ Year $_{i, j . j}+\mathrm{c}+v_{i, j}$

with $Y$ : value added ; $K$ : capital ; L: labor ; age: firm's age (in years) ; Cert* ${ }^{*}$ quality certification ; Lic* : foreign licensed technology ; Export*: export status; Foreign*: foreign ownership of capital ; Infra, ICT, H, Fin, Gov, CrimePol, Comp: investment climate composite indicators (see Annex 2 for their definition); Reg: region fixedeffects, Year: year of survey, $c$ : intercept, $v$ : error term, $\alpha \beta, \gamma_{1 \text { to } 5}, \varepsilon_{1 \text { to } 7}, \varphi_{1,2}:$ parameters to be estimated, $i / j$ : observation/country index, respectively. *Binary variables.

As regards the control variables, exporting (Export) is a learning process, which enables companies to improve productivity through economies of scale, learning from customers and competitors, and from competitive pressure (Balassa, 1988, and Coe and Helpman, 1995). Foreign ownership (Foreign) may increase a firm's productivity if foreign investors bring new technologies and management techniques

\footnotetext{
${ }^{17}$ Initial variables are standardized for the purpose of the $P C A$ methodology.
} 
(Borensztein, De Gregorio and Lee, 1998). Licenses from foreign companies (Lic) may also contribute to productive performance through foreign knowledge and technology transfer (Basant and Fikkert, 1996; Branstetter and Chen, 2006). Quality certification (Cert) can help certified firms to be more efficient (Lima et al, 2004; Koc, 2007), although not in all cases (Lima et al, 2000). Older firms may benefit from greater experience and established contacts with customers and providers, while younger firms may face a learning procedure and higher risks of failure. Although the positive link between firm age (age) and performance has been highlighted in several studies (Haltiwanger et al, 1999, for firm productivity; Das, 1995; Shanmugam and Bhaduri, 2002, for firm growth), several authors suggest an opposite relationship, linked to the innovation potential of young firms (Barron et al, 1994; Correa et al, 2003).

With the empirical model emphasizing the relationship between these variables and firm productivity, the expected sign of the estimated coefficients is positive. The business environment indicators reflect a capacity and are also expected to positively affect firm performance (see section 5 for the construction of the composite indicators).

\subsection{Estimation Results}

\subsubsection{The Initial Model}

Equation (4) was estimated by industry on our panel of 70 countries. Because of space constraints (the same estimations are repeated under different conditions in the next 3 sections), the results are presented for total manufacturing only. Results by sector are introduced in the penultimate set of regressions, when we summarize the findings of our best specification. We can however say that the estimation results confirm the choice of estimating a production function by industry, although the elasticity of factors is still not always in line with the literature ${ }^{18}$. Nevertheless, returns to scale are more often closer to 1 (in the manufacturing sector taken as a whole as well) than in the case of the first production functions (without the factors for productivity, see section 4). Some differences in the productive technology are also linked to the year of survey, the region, and sector specific conditions, because sector, region, and year fixed-effects are statistically significant. ${ }^{19}$

More interestingly for the purpose of the paper, our estimations do not reject the hypothesis that differences in investment climate result in differences in firm productivity. This is true for most aspects of the business environment (see Table 3). Our results confirm that infrastructure quality (Infra), access to ICT and financing (Fin), skills and expertise of the labor force $(H)$, quality of the relations with the government (Gov) (relative to corruption and regulation in particular), and competition (Comp) (weakly significant), are positively linked to firm performance. The regression results, however, have still to be treated with caution, as they highlight correlations rather than causal relations. Nevertheless, we can already say that this outcome, which is consistent with the theory,

\footnotetext{
${ }^{18}$ It is interesting to note that, in this specification, the coefficients of technology are negatively affected. This modification displays the potential limitation that would be faced when estimating the TFP determinants through the two-stage method, as discussed in section 3. For all sectors, the coefficients of labor are smaller than in our first model.

${ }^{19}$ Sector fixed-effects are introduced when estimating the total manufacturing production function. They represent the specific conditions attached to each industry.
} 
makes a contribution to the empirical literature by highlighting, for a larger than usual sample of firms, from a wider than usual variety of industries and countries, the links with a more substantial set of investment climate variables. It is of major importance for developing countries, especially for the lagging economies, whose business environment have proved to be insufficient (see sections 4 and 5). An improvement of different dimensions of the environment for firms would help them to catch up with more productive and competitive countries.

Table-3- Production Function with Composite Indicators of Business Environment Variables: Estimation Results

(Dependant Variable: Log of Firm Value-Added)

\begin{tabular}{|c|c|c|c|c|c|c|}
\hline Manufacturing & $(1)$ & $\left(1^{\prime}\right)$ & $(2)$ & $\left(2^{\prime}\right)$ & (3) & $\left(3^{\prime}\right)$ \\
\hline $\mathbf{L}$ & $\begin{array}{c}0.671 * * * \\
(30.86)\end{array}$ & $\begin{array}{c}0.663 * * * \\
(30.55)\end{array}$ & $\begin{array}{c}0.675 * * * \\
(32.33)\end{array}$ & $\begin{array}{c}0.669 * * * \\
(31.80)\end{array}$ & $\begin{array}{c}0.673 * * * \\
(32.48)\end{array}$ & $\begin{array}{c}0.667 * * * \\
(31.93)\end{array}$ \\
\hline $\mathbf{K}$ & $\begin{array}{c}0.254 * * * \\
(19.48)\end{array}$ & $\begin{array}{c}0.255^{* * *} * \\
(19.69)\end{array}$ & $\begin{array}{c}0.249 * * * \\
(19.66)\end{array}$ & $\begin{array}{c}0.250 * * * \\
(19.76)\end{array}$ & $\begin{array}{c}0.249 * * * \\
(19.76)\end{array}$ & $\begin{array}{c}0.250 * * * \\
(19.86)\end{array}$ \\
\hline Year & $\begin{array}{c}-0.019 * * \\
(-3.13)\end{array}$ & $\begin{array}{c}-0.018^{* *} \\
(-2.94)\end{array}$ & $\begin{array}{c}-0.023 * * * \\
(-3.91)\end{array}$ & $\begin{array}{c}-0.022 * * * \\
(-3.75)\end{array}$ & $\begin{array}{c}-0.023 * * * \\
(-3.92)\end{array}$ & $\begin{array}{c}-0.022 * * * \\
(-3.79)\end{array}$ \\
\hline Age & $\begin{array}{c}0.0025^{* *} \\
(2.97)\end{array}$ & $\begin{array}{c}0.0029 * * * \\
(3.48)\end{array}$ & $\begin{array}{c}0.0025^{* *} \\
(3.06)\end{array}$ & $\begin{array}{c}0.0029 * * * \\
\quad(3.58)\end{array}$ & $\begin{array}{c}0.0025 * * \\
(3.03)\end{array}$ & $\begin{array}{c}0.0029 * * * \\
(3.56)\end{array}$ \\
\hline Quality Certification_^ & $\begin{array}{c}0.139 * * \\
(3.05)\end{array}$ & $\begin{array}{c}0.141^{* *} \\
(3.09)\end{array}$ & $\begin{array}{c}0.132 * * \\
(3.02)\end{array}$ & $\begin{array}{c}0.131 * * \\
(3.00)\end{array}$ & $\begin{array}{c}0.134 * * \\
(3.09)\end{array}$ & $\begin{array}{c}0.134 * * \\
(3.08)\end{array}$ \\
\hline Foreign Lic Tech_^ & $\begin{array}{c}0.0604 \\
(1.24)\end{array}$ & $\begin{array}{c}0.0567 \\
(1.16)\end{array}$ & $\begin{array}{c}0.0704 \\
(1.50)\end{array}$ & $\begin{array}{c}0.0656 \\
(1.40)\end{array}$ & $\begin{array}{c}0.0693 \\
(1.48)\end{array}$ & $\begin{array}{c}0.0644 \\
(1.38)\end{array}$ \\
\hline $\mathbf{X}^{\wedge}$ & $\begin{array}{c}0.128 * * \\
(3.15)\end{array}$ & $\begin{array}{c}0.129 * * \\
(3.21)\end{array}$ & $\begin{array}{c}0.142^{* * * *} \\
(3.58)\end{array}$ & $\begin{array}{c}0.141 * * * \\
(3.56)\end{array}$ & $\begin{array}{c}0.142^{* * * *} \\
(3.58)\end{array}$ & $\begin{array}{c}0.141 * * * \\
(3.56)\end{array}$ \\
\hline Foreign_K_^ & $\begin{array}{c}0.266^{* * * *} \\
(4.97)\end{array}$ & $\begin{array}{c}0.258 * * * \\
(4.85)\end{array}$ & $\begin{array}{c}0.285^{* * *} * \\
(5.41)\end{array}$ & $\begin{array}{c}0.277 * * * \\
(5.32)\end{array}$ & $\begin{array}{c}0.290 * * * \\
(5.52)\end{array}$ & $\begin{array}{c}0.282^{* * *} * \\
(5.42)\end{array}$ \\
\hline H_PCA ${ }^{\wedge \wedge}$ & $\begin{array}{c}0.122 * * * \\
(4.85)\end{array}$ & & $\begin{array}{c}0.124 * * * \\
(5.09)\end{array}$ & & $\begin{array}{c}0.126^{* * * *} \\
(5.20)\end{array}$ & \\
\hline Training_^ & & $\begin{array}{c}0.156^{* * * *} \\
(4.21)\end{array}$ & & $\begin{array}{c}0.155 * * * \\
(4.28)\end{array}$ & & $\begin{array}{c}0.157 * * * \\
(4.34)\end{array}$ \\
\hline Fin_PCA ${ }^{\wedge} \wedge$ & $\begin{array}{c}0.322^{* * *} \\
(13.68)\end{array}$ & $\begin{array}{c}0.322^{* * * *} \\
(13.69)\end{array}$ & $\begin{array}{c}0.296^{* * * *} \\
(13.01)\end{array}$ & $\begin{array}{c}0.299 * * * \\
(13.13)\end{array}$ & $\begin{array}{c}0.296^{* * * *} \\
(13.24)\end{array}$ & $\begin{array}{c}0.299 * * * \\
(13.35)\end{array}$ \\
\hline Infra_PCA ${ }^{\wedge} \wedge$ & $\begin{array}{c}0.0402 * \\
(1.95)\end{array}$ & $\begin{array}{c}0.0407^{*} \\
(1.98)\end{array}$ & $\begin{array}{c}0.0142 \\
(0.71)\end{array}$ & $\begin{array}{c}0.0126 \\
(0.63)\end{array}$ & & \\
\hline Power $^{\wedge}$ & & & & & $\begin{array}{c}0.0622^{*} \\
(1.94)\end{array}$ & $\begin{array}{r}0.0555 \\
(1.73)\end{array}$ \\
\hline $\mathbf{I C T}_{\mathbf{A C C A}}{ }^{\wedge \wedge}$ & $\begin{array}{c}0.219^{* * * *} \\
(12.02)\end{array}$ & $\begin{array}{c}0.216^{* * * *} \\
(11.86)\end{array}$ & $\begin{array}{c}0.225^{* * *} * \\
(12.86)\end{array}$ & $\begin{array}{c}0.223 * * * \\
(12.61)\end{array}$ & $\begin{array}{c}0.223 * * * \\
(12.79)\end{array}$ & $\begin{array}{c}0.221 * * * \\
(12.54)\end{array}$ \\
\hline Gov_PCA ${ }^{\wedge \wedge}$ & $\begin{array}{c}-0.0607 * * \\
(-2.89)\end{array}$ & $\begin{array}{c}-0.0641^{* *} \\
(-3.05)\end{array}$ & & & & \\
\hline Corruption_^$^{\wedge}$ & & & $\begin{array}{c}0.152^{*} \\
(2.44)\end{array}$ & $\begin{array}{c}0.147 * \\
(2.36)\end{array}$ & $\begin{array}{c}0.151 * \\
(2.43)\end{array}$ & $\begin{array}{c}0.146^{*} \\
(2.35)\end{array}$ \\
\hline CrimPol_PCA ${ }^{\wedge \wedge}$ & $\begin{array}{c}-0.104 * * * \\
(-3.50)\end{array}$ & $\begin{array}{c}-0.1000 * * * \\
(-3.36)\end{array}$ & $\begin{array}{c}-0.141 * * * \\
(-5.19)\end{array}$ & $\begin{array}{c}-0.141 * * * \\
(-5.19)\end{array}$ & $\begin{array}{c}-0.140 * * * \\
(-5.23)\end{array}$ & $\begin{array}{c}-0.141 * * * \\
(-5.24)\end{array}$ \\
\hline Comp_PCA $^{\wedge \wedge}$ & $\begin{array}{l}0.041 \\
(1.53)\end{array}$ & $\begin{array}{l}0.044 \\
(1.63)\end{array}$ & $\begin{array}{l}0.038 \\
(1.44)\end{array}$ & $\begin{array}{c}0.04 \\
(1.52)\end{array}$ & $\begin{array}{c}0.04 \\
(1.52)\end{array}$ & $\begin{array}{l}0.041 \\
(1.61)\end{array}$ \\
\hline Intercept & $\begin{array}{c}46.8^{* * * *} \\
(3.75)\end{array}$ & $\begin{array}{c}44.2^{* * * *} \\
(3.55)\end{array}$ & $\begin{array}{c}53.9 * * * \\
(4.54)\end{array}$ & $\begin{array}{c}51.7 * * * \\
(4.37)\end{array}$ & $\begin{array}{c}53.7 * * * \\
(4.55)\end{array}$ & $\begin{array}{c}51.8 * * * \\
(4.40)\end{array}$ \\
\hline ProbaCRScale & 0,00 & 0,00 & 0,00 & 0,00 & 0,00 & 0,00 \\
\hline 'e K/e L & 0,38 & 0,38 & 0,37 & 0,37 & 0,37 & 0,37 \\
\hline $\mathbf{R}^{2}$ & 0,78 & 0,08 & 0,77 & 0,78 & 0,77 & 0,78 \\
\hline Observations & 4717 & 4745 & 5029 & $\mathbf{5 0 7 0}$ & 5062 & 5104 \\
\hline
\end{tabular}

Source: Authors' estimations. 
Note: $K$ : capital (in $\log$ ); L: labor (in $\log$ ); Year: year of survey; Age: firm's age (in years); Cert: quality certification; Lic: foreign licensed technology; Export: export status; Foreign_K: foreign ownership of capital; Training: training of employees; Power: power shortages; Corruption: gift when inspected; Infra, ICT, H, Fin, Gov, CrimePol, Comp: investment climate (IC) composite indicators (see Annex 2 for their definition). The expected sign of the IC is positive. Age, Cert, Lic, Foreign, Export, Training, Power, and Corruption are also expected to have a positive coefficient. Regressions contain country, region and sector fixed-effects. Production functions are estimated by a pool OLS. Heteroskedasticity-robust t-students are reported in parentheses. $* * *, * *, *$, and ' denote significance at the $0.1 \%, 1 \%, 5 \%$, and $10 \%$ levels, respectively. ${ }^{\wedge}$ Binary variable. ${ }^{\wedge} \wedge$ Aggregated indicator. e K: elasticity of capital ; e L: elasticity of labor; CR: constant returns.

The findings show, however, some variations. It appears that some results are less robust than others. This is true for the quality of infrastructure (Infra), and for the relation with the government (Gov). The difficulties could result from the aggregation process that may sometimes give inappropriate results. This might be the case for the government relation index (Gov), which may incorporate too many variables of unequal quality (see section 5). This may also be true for the infrastructure indicator (Infra), for which some initial variables may not be reliable. When proxying these 2 indicators with a unique variable, we end up with better results (coefficients are significant with the right sign, see columns 3 and 4 in Table 3 where Gov is replaced by an indicator of corruption, and columns 4 and 5 where power shortages are taken as proxy of Infra).

This finding might also reflect the fact that the direction of the impact of some investment climate variables which affect the government relations indicator (Gov) (corruption and regulation in particular) is questionable. Although one part of the literature outlines a negative role for these factors on firm productivity, some research does not confirm this result, especially in the case of micro firms which could be less constrained by both these constraints (see discussion in section 5). This contradictory effect could explain a negative sign or a lower significance of the indicator of government relations (Gov), when explaining firm-level TFP.

In the case of security and political stability (CrimePol), we may face an endogeneity issue. All aggregate indicators having been constructed as a capacity (see section 5), a positive sign is expected for all investment climate indicators. However, CrimePol has a negative significant relationship with firm-level TFP. In more prosperous developing countries, where firms may perform better, it is not rare to find a high criminality rate. Our findings would, in that case, show a correlation, rather than a causality. This does not come as a surprise, knowing that we have not yet addressed the endogeneity issue. These questions are discussed more extensively below.

Our model validates in addition the role of some plants' characteristics in explaining firm-level productivity (TFP). This is the case for the variable age, which appears to be a positive factor of accumulation of knowledge and experience (Haltiwanger et al, 1999).

Also, export orientation (Export) explains the externalities linked to this activity. This result meets with what we know about the manufacturing sector, where external competitive markets are a stimulating source for a high productivity level. The decision to export appears to be another means of stimulating firm productivity, as well as contributing to developing countries' industrial growth and the catch-up process. This interpretation is reinforced by the significance of the competition variable (Comp) which shows that operating at a higher level of competition (international versus local) stimulates firm productive performance. The same conclusions can be drawn for foreign participation 
in capital (Foreign) whose significance validates the hypothesis of the benefit of access to foreign knowledge and technology. The role of the 2 other variables related to firms' foreign orientation ("quality certification" (Cert) and "foreign license technology" (Lic)) are also validated by the data. This makes foreign exposure an important factor in firms' productive performance and competitiveness. This finding is all the more important in the growing context of globalization faced by the developing world, where outward orientation could contribute to technological catch up, domestic growth, and better integration into the world market.

\subsubsection{Treating Measurement Errors and Missing Observation Issues}

In this section, we build on previous findings and address some of the data issues previously stressed. Like Dollar et al (2005), we partly control for endogeneity by using the country-region-size average of the business environment variables. This method permits us to mitigate measurement errors, and the missing observation issue (the number of observations at 6,831 for the total manufacturing, is increased by 1,500 to 2,000 compared to the previous sets of regressions). 
Table-4- Production Function with Composite Indicators of Country-Region-Size Average of Business Environment Variables: Estimation Results

(Dependant Variable: Log of Firm Value-Added)

\begin{tabular}{|c|c|c|c|c|}
\hline Manufacturing & (1) & (1)' & (2) & $(2)^{\prime}$ \\
\hline $\mathbf{L}$ & $\begin{array}{c}0.671 * * * \\
(32.47)\end{array}$ & $\begin{array}{c}0.687 * * * \\
(32.96)\end{array}$ & $\begin{array}{c}0.653 * * * \\
(32.09)\end{array}$ & $\begin{array}{c}0.677 * * * * \\
(32.73)\end{array}$ \\
\hline $\mathbf{K}$ & $\begin{array}{c}0.260 * * * \\
(23.36)\end{array}$ & $\begin{array}{c}0.260 * * * \\
(23.33)\end{array}$ & $\begin{array}{c}0.260 * * * \\
(23.52)\end{array}$ & $\begin{array}{c}0.261^{* * *} \\
(23.46)\end{array}$ \\
\hline Year & $\begin{array}{l}-0.002 \\
(-0.39)\end{array}$ & $\begin{array}{l}-0.003 \\
(-0.60)\end{array}$ & $\begin{array}{l}-0.006 \\
(-1.06)\end{array}$ & $\begin{array}{l}-0.007 \\
(-1.28)\end{array}$ \\
\hline Age & $\begin{array}{c}0.0022 * * \\
(2.96)\end{array}$ & $\begin{array}{c}0.0019 * \\
(2.54)\end{array}$ & $\begin{array}{c}0.0023 * * \\
(3.06)\end{array}$ & $\begin{array}{c}0.0018 * \\
(2.41)\end{array}$ \\
\hline Quality Certification $^{\wedge}$ & $\begin{array}{c}0.186 * * * \\
(4.92)\end{array}$ & $\begin{array}{c}0.192 * * * \\
(5.09)\end{array}$ & $\begin{array}{c}0.181 * * * \\
(4.78)\end{array}$ & $\begin{array}{c}0.190 * * * \\
(5.02)\end{array}$ \\
\hline Foreign Lic Tech^ ${ }^{\wedge}$ & $\begin{array}{c}0.147 * * * \\
(3.53)\end{array}$ & $\begin{array}{c}0.146 * * * \\
(3.51)\end{array}$ & $\begin{array}{c}0.136 * * \\
(3.25)\end{array}$ & $\begin{array}{c}0.135 * * \\
(3.25)\end{array}$ \\
\hline $\mathbf{X}^{\wedge}$ & $\begin{array}{c}0.220 * * * \\
(6.67)\end{array}$ & $\begin{array}{c}0.218 * * * \\
(6.64)\end{array}$ & $\begin{array}{c}0.227 * * * \\
(6.85)\end{array}$ & $\begin{array}{c}0.224 * * * \\
(6.80)\end{array}$ \\
\hline Foreign_K^ ${ }^{\wedge}$ & $\begin{array}{c}0.273 * * * \\
(6.18)\end{array}$ & $\begin{array}{c}0.274 * * * \\
(6.21)\end{array}$ & $\begin{array}{c}0.271 * * * \\
(6.15)\end{array}$ & $\begin{array}{c}0.273 * * * \\
(6.21)\end{array}$ \\
\hline H_PCA ${ }^{\wedge} \wedge$ & $\begin{array}{c}0.072 * * * \\
(3.41)\end{array}$ & & $\begin{array}{c}0.098 * * * \\
(4.65)\end{array}$ & \\
\hline Exp. Manager & & $\begin{array}{c}0.020 * * \\
(4.21)\end{array}$ & & $\begin{array}{c}0.028 * * * \\
(6.04)\end{array}$ \\
\hline Fin_PCA ${ }^{\wedge} \wedge$ & $\begin{array}{c}0.267 * * * \\
(9.61)\end{array}$ & $\begin{array}{c}0.266^{* * *} \\
(9.80)\end{array}$ & $\begin{array}{c}0.131 * * * \\
(5.10)\end{array}$ & $\begin{array}{c}0.134 * * * \\
(5.30)\end{array}$ \\
\hline Infra_PCA ${ }^{\wedge \wedge}$ & $\begin{array}{c}0.093 * * \\
(5.28)\end{array}$ & $\begin{array}{c}0.099 * * * \\
(5.61)\end{array}$ & $\begin{array}{l}0.027 \\
(1.49)\end{array}$ & $\begin{array}{c}0.035^{*} \\
(1.91)\end{array}$ \\
\hline ICT_PCA ${ }^{\wedge \wedge}$ & $\begin{array}{c}0.131 * * * \\
(7.32)\end{array}$ & $\begin{array}{c}0.109 * * * \\
(5.30)\end{array}$ & $\begin{array}{c}0.153 * * * \\
(8.79)\end{array}$ & $\begin{array}{c}0.118 * * * \\
(5.76)\end{array}$ \\
\hline Gov_PCA $^{\wedge} \wedge$ & $\begin{array}{c}-0.118 * * * \\
(-6.14)\end{array}$ & $\begin{array}{c}-0.111 * * * \\
(-5.71)\end{array}$ & & \\
\hline Corruption $^{\wedge}$ & & & $\begin{array}{c}1.042 * * * \\
(5.47)\end{array}$ & $\begin{array}{c}1.116^{* * * *} \\
(5.85)\end{array}$ \\
\hline CrimPol_PCA ${ }^{\wedge \wedge}$ & $\begin{array}{c}-0.00439 \\
(-0.17)\end{array}$ & $\begin{array}{c}-0.0441 \\
(-1.77)\end{array}$ & $\begin{array}{c}-0.105 * * * \\
(-5.42)\end{array}$ & $\begin{array}{c}-0.153 * * * \\
(-8.46)\end{array}$ \\
\hline Comp_PCA $^{\wedge \wedge}$ & $\begin{array}{c}-0.069 * * * \\
(-3.43)\end{array}$ & $\begin{array}{l}-0.05^{*} \\
(-2.37)\end{array}$ & $\begin{array}{l}-0.032 \\
(-1.45)\end{array}$ & $\begin{array}{c}0.001 \\
(0.05)\end{array}$ \\
\hline Intercept & $\begin{array}{r}11.95 \\
(1.13) \\
\end{array}$ & $\begin{array}{c}13.71 \\
(1.30) \\
\end{array}$ & $\begin{array}{c}16.98 \\
(1.60) \\
\end{array}$ & $\begin{array}{c}18.65 \\
(1.76)^{\prime} \\
\end{array}$ \\
\hline ProbaCRScale & 0,00 & 0,00 & 0,00 & 0,00 \\
\hline 'e K/e L & 0,39 & 0,38 & 0,40 & 0,39 \\
\hline $\mathbf{R}^{2}$ & 0,76 & 0,76 & 0,76 & 0,76 \\
\hline Observations & 6831 & 6831 & 6831 & 6831 \\
\hline
\end{tabular}

Source: Authors' estimations

Note: K: capital (in log); L: labor (in log); Year: year of survey Age: firm's age (in years); Cert: quality certification; Lic: foreign licensed technology; Export: export status; Foreign_K: foreign ownership of capital; Exp. Manager: experience of the top manager (in years); Corruption: gift when inspected; Infra, ICT, H, Fin, Gov, CrimePol, Comp: investment climate (IC) composite indicators (see Annex 2 for their definition). The expected sign of the IC indicators is positive. Variables Age, Cert, Lic, Foreign, Export, Exp. Manager, and Corruption are also expected to have a positive coefficient. Regressions contain country, region and sector fixed-effects. Production functions are estimated by a pool OLS Heteroskedasticity-robust t-students are reported in parentheses. $* * *, * * *$, and ' denote significance at the $0.1 \%, 1 \%, 5 \%$, and $10 \%$ levels, respectively. ${ }^{\wedge}$ Binary variable. ${ }^{\wedge} \wedge$ Aggregated indicator. e K: elasticity of capital ; e L: elasticity of labor; CR: constant returns. 
The estimation results are presented in Table 4 for the manufacturing sector only (for the same reasons as explained above). Table 4 highlights the differences and the similarities compared to Table 3 . As regards the technology of production, incorporation of more data, as well as better quality data does not modify the elasticity of capital and labor. This could mean that, although the previous estimation results were unsatisfactory, endogeneity and measurement errors did not lead to a biased estimation of the impact of the traditional factors of production. Another possibility could be that we do not see any change because the improvement in the quality of data is insufficient. The findings regarding the technology of production and the branches are for the moment unchanged. As for sectors, year of survey, and regions fixed-effects, they still contribute to the observed differences in productivity level. The same conclusion can be drawn for age (age), and security and political stability (CrimePol), (which still shows a negative and significant relationship with firm performance).

The impact of most other productivity factors is more affected by the bias due to the unsatisfactory data quality. This is the case for export status (Export), quality certification (Cert), foreign licensed technology (Lic), human capacity $(H)$, infrastructure (Infra), ICT and corruption (Corr). Although the amplitude of variation between the two sets of regressions is not very high, half of the coefficients show an upward trend (this is the case of the variables measuring the outward orientation of the firms whose coefficients are stronger than previously), and half a downward trend. Competition (Comp) which was weakly significant in the previous version, is now not significant. The infrastructure indicator (Infra) was significant in the previous estimations, this is no longer the case.

However, except in these last 2 cases, the estimations still validate the role of the other business environment dimensions, and firm characteristics. Conclusions are nevertheless difficult to draw, and more investigations need to be carried out. In the next section, we propose to better address the issues of measurement errors and of endogeneity, by replacing the initial business environment variables by their predictions when processing the composite indicators.

\subsubsection{Treating Endogeneity (1): Prediction of the Investment Climate Variables}

In the next set of regressions, we substitute for the composite investment climate indicators processed from the observed values of the initial variables (section 6.2.1) or from their country-region-size average (section 6.2.2), a new set of indicators based on the predicted values of these observations. In addition to correcting for measurement errors, the use of predictions provides a much better way to deal with endogenous independent variables than their country-region-size average.

Several models of prediction are used. The first choice was to use linear regressions for all initial variables. This model is not presented here because it was not satisfactory. The second choice aimed to select a more appropriate specification for each type of variable. We decided to apply linear regressions to continuous variables, probit, or logit model to binomial quantities, and ordered probit or logit models to multinomial observations. All the business environment data were instrumented by the same set of independent (exogenous) variables. We chose to regress on each investment climate initial variable, the country, region, sector, year of survey dummies, the firm's number of workers 3 years prior to the survey, the legal status of the firm, and the fact of being part of a larger enterprise or not. 
The estimation results of equation (4), which incorporate the composite investment climate indicators processed from the predictions of the observed initial variables, are presented for total manufacturing (Table 5), and for each sector (Table 6). The results for technology of production are now more in line with the literature. This is true for manufacturing as a whole (Table 5), but also for almost all sectors (Tables 6a and 6b), except for some heavy industries (Machinery and Transport essentially) for which elasticity of capital compared to labor is still low. Constant returns to scale are almost always validated by the data, except in Wood \& Furniture and, to a lesser extent, Chemicals ${ }^{20}$. These findings confirm that previous estimations were probably biased. They also indicate that addressing data limitation problems and using a pertinent statistical approach, provide a better quantification of the relations under investigation. In addition, sectors (for total manufacturing), year of survey and regions fixedeffects still contribute to the observed differences in firm performance.

Another interesting finding is related to the business environment, all of whose dimensions participate, with the expected sign, in firm-level productivity differences. This is true for total manufacturing (except for the competition variable (Comp)), as well as for all sectors (with some differences across them).

The role of competition (Comp) in particular is validated by the data in half of the sectors only: Textile, Garment, Leather, Wood \& Furniture and Transports. This result, however, is interesting. These industries are particularly exposed to international competition, and more firms operate at the international level. In this case competition constitutes an engine to boost their productivity. But the same firms probably also benefit from economies of scale linked to operating in a big market, and externalities linked to their access to international knowledge.

Security and political stability (CrimePol), and, surprisingly, traditional infrastructure (Infra), appear to be less robust dimensions of the investment climate in several sectors as well. Some questions in particular concern the Leather, Rubber \& Plastic and Machinery industries for which 3 investment climate indicators do not seem to contribute to firm performance, and to a lesser extent, the Garment, Chemicals and Metal Products industries which is the case for 2 business environment variables (see Tables $6 \mathrm{a}$ and $6 \mathrm{~b})$.

However, human capacity $(H)$, financing (Fin), ICT, and relation with the government (Gov), are dimensions common to all sectors (except Leather for 2 of them).

These results reinforce our previous findings. If we have already highlighted the probable impact of almost all aspects of the investment climate, we are now able to include the role of security and political stability (CrimePol), and competition (Comp) as factors of performance. The results prove

\footnotetext{
${ }^{20}$ This is also true in the case of Food and Leather when using the human capital composite indicator $(H)$, instead of the number of years of experience of the manager as proxy (Tables A3a and A3b in Annex 4).
} 
Table-5- Production Function with Composite Indicators of

Predicted Value of Business Environment Variables ${ }^{\wedge \wedge}$ : Estimation Results

(Dependant Variable: Log of Firm Value-Added)

\begin{tabular}{|c|c|c|c|c|c|c|c|c|c|}
\hline Manufacturing & (1) & $\left(\mathbf{1}^{\prime}\right)$ & $\left(1^{\prime \prime}\right)$ & (2) & $\left(2^{\prime}\right)$ & $\left(2^{\prime \prime}\right)$ & (3) & $\left(3^{\prime}\right)$ & $\left(3^{\prime \prime}\right)$ \\
\hline $\mathbf{L}$ & $\begin{array}{c}0.706^{* * * *} \\
(29.50)\end{array}$ & $\begin{array}{c}0.679 * * * \\
(25.23)\end{array}$ & $\begin{array}{c}0.734 * * * \\
(29.02)\end{array}$ & $\begin{array}{c}0.712 * * * \\
(29.58)\end{array}$ & $\begin{array}{c}0.677 * * * \\
(25.11)\end{array}$ & $\begin{array}{c}0.743 * * * \\
(29.12)\end{array}$ & $\begin{array}{c}0.686 * * * \\
(26.96)\end{array}$ & $\begin{array}{c}0.659 * * * \\
(23.38)\end{array}$ & $\begin{array}{c}0.714 * * * \\
(26.96)\end{array}$ \\
\hline $\mathbf{K}$ & $\begin{array}{c}0.249 * * * \\
(20.24)\end{array}$ & $\begin{array}{c}0.249 * * * \\
(20.24)\end{array}$ & $\begin{array}{c}0.251 * * * \\
(20.32)\end{array}$ & $\begin{array}{c}0.246 * * * \\
(20.01)\end{array}$ & $\begin{array}{c}0.246 * * * \\
(20.03)\end{array}$ & $\begin{array}{c}0.248 * * * \\
(20.12)\end{array}$ & $\begin{array}{c}0.245 * * * \\
(19.96)\end{array}$ & $\begin{array}{c}0.245 * * * \\
(20.00)\end{array}$ & $\begin{array}{c}0.247 * * * \\
(20.08)\end{array}$ \\
\hline Year & $\begin{array}{l}-0.012 \\
(-1.74)\end{array}$ & $\begin{array}{l}-0.005 \\
(-0.70)\end{array}$ & $\begin{array}{c}-0.016^{*} \\
(-2.28)\end{array}$ & $\begin{array}{c}-0.02 * * \\
(-2.77)\end{array}$ & $\begin{array}{l}-0.01 \\
(-1.34)\end{array}$ & $\begin{array}{c}-0.024 * * * \\
(-3.33)\end{array}$ & $\begin{array}{c}-0.025 * * * \\
(-3.43)\end{array}$ & $\begin{array}{l}-0.014 \\
(-1.87)\end{array}$ & $\begin{array}{c}-0.031 \text { *** } \\
(-4.18)\end{array}$ \\
\hline Age & $\begin{array}{c}0.0018^{*} \\
(2.05)\end{array}$ & $\begin{array}{c}0.0022^{*} \\
(2.51)\end{array}$ & $\begin{array}{c}0.0015 \\
(1.75)\end{array}$ & $\begin{array}{c}0.0016 \\
(1.82)\end{array}$ & $\begin{array}{c}0.0021^{*} \\
(2.48)\end{array}$ & $\begin{array}{c}0.0013 \\
(1.48)\end{array}$ & $\begin{array}{c}' 0.0015 \\
(1.74)\end{array}$ & $\begin{array}{c}0.0021^{*} \\
(2.45)\end{array}$ & $\begin{array}{c}0.0012 \\
(1.35)\end{array}$ \\
\hline QualityCertification $^{\wedge}$ & $\begin{array}{c}0.211 * * * \\
(4.95)\end{array}$ & $\begin{array}{c}0.214 * * * \\
(5.01)\end{array}$ & $\begin{array}{c}0.223 * * * \\
(5.23)\end{array}$ & $\begin{array}{c}0.201 * * * \\
(4.73)\end{array}$ & $\begin{array}{c}0.204 * * * \\
(4.81)\end{array}$ & $\begin{array}{c}0.215 * * * \\
(5.08)\end{array}$ & $\begin{array}{c}0.194 * * * \\
(4.57)\end{array}$ & $\begin{array}{c}0.199 * * * \\
(4.69)\end{array}$ & $\begin{array}{c}0.207 * * * \\
(4.90)\end{array}$ \\
\hline Foreign Lic Tech ${ }^{\wedge}$ & $\begin{array}{c}0.140 * * \\
(3.11)\end{array}$ & $\begin{array}{c}0.135^{* * *} \\
(3.00)\end{array}$ & $\begin{array}{c}0.141 * * \\
(3.13)\end{array}$ & $\begin{array}{c}0.135^{* *} \\
(3.02)\end{array}$ & $\begin{array}{c}0.130 * * \\
(2.89)\end{array}$ & $\begin{array}{c}0.136^{* *} \\
(3.03)\end{array}$ & $\begin{array}{c}0.129 * * \\
(2.89)\end{array}$ & $\begin{array}{c}0.125^{* *} \\
(2.77)\end{array}$ & $\begin{array}{c}0.129^{* *} \\
(2.88)\end{array}$ \\
\hline $\mathbf{X}^{\wedge}$ & $\begin{array}{c}0.176^{* * *} \\
(4.74)\end{array}$ & $\begin{array}{c}0.182 * * * \\
(4.92)\end{array}$ & $\begin{array}{c}0.181 \text { *** } \\
(4.91)\end{array}$ & $\begin{array}{c}0.178 * * * \\
(4.82)\end{array}$ & $\begin{array}{c}0.185^{* * * *} \\
(5.01)\end{array}$ & $\begin{array}{c}0.185^{* * *} * \\
(5.05)\end{array}$ & $\begin{array}{c}0.178 * * * \\
(4.82)\end{array}$ & $\begin{array}{c}0.186^{* * * *} \\
(5.03)\end{array}$ & $\begin{array}{c}0.185^{* * * *} \\
(5.04)\end{array}$ \\
\hline Foreign_K $\mathbf{K}^{\wedge}$ & $\begin{array}{c}0.321 * * * \\
(6.27)\end{array}$ & $\begin{array}{c}0.313 * * * \\
(6.13)\end{array}$ & $\begin{array}{c}0.327 * * * \\
(6.40)\end{array}$ & $\begin{array}{c}0.318 * * * \\
(6.22)\end{array}$ & $\begin{array}{c}0.307 * * * \\
(6.02)\end{array}$ & $\begin{array}{c}0.325 * * * \\
(6.36)\end{array}$ & $\begin{array}{c}0.313 * * * \\
(6.13)\end{array}$ & $\begin{array}{c}0.303 * * * \\
(5.95)\end{array}$ & $\begin{array}{c}0.320 * * * \\
(6.26)\end{array}$ \\
\hline H_PCA ${ }^{\wedge} \wedge$ & $\begin{array}{c}0.143 * * * \\
(4.37)\end{array}$ & & & $\begin{array}{c}0.180 * * * \\
(5.52)\end{array}$ & & & $\begin{array}{c}0.186 * * * \\
(5.71)\end{array}$ & & \\
\hline Training $^{\wedge}$ & & $\begin{array}{l}0.242 \\
(1.60)\end{array}$ & & & $\begin{array}{l}0.319 * \\
(2.10)\end{array}$ & & & $\begin{array}{c}0.293^{*} \\
(1.95)\end{array}$ & \\
\hline Exp. Manager & & & $\begin{array}{c}0.0291 * * * \\
(5.45)\end{array}$ & & & $\begin{array}{c}0.0340 * * * \\
(6.31)\end{array}$ & & & $\begin{array}{c}0.0363 * * * * \\
(6.70)\end{array}$ \\
\hline Fin_PCA ${ }^{\wedge \wedge}$ & $\begin{array}{c}0.222 * * * \\
(6.80)\end{array}$ & $\begin{array}{c}0.223 * * * \\
(6.52)\end{array}$ & $\begin{array}{c}0.246^{* * * *} \\
(7.60)\end{array}$ & $\begin{array}{c}0.202 * * * \\
(7.06)\end{array}$ & $\begin{array}{c}0.213 * * * \\
(6.90)\end{array}$ & $\begin{array}{c}0.229 * * * \\
(8.18)\end{array}$ & $\begin{array}{c}0.206^{* * * *} \\
(7.19)\end{array}$ & $\begin{array}{c}0.219 * * * \\
(7.10)\end{array}$ & $\begin{array}{c}0.233 * * * \\
(8.38)\end{array}$ \\
\hline Infra_PCA ${ }^{\wedge \wedge}$ & $\begin{array}{c}-0.0483^{* *} \\
(-3.09)\end{array}$ & $\begin{array}{c}-0.0468^{* *} \\
(-3.01)\end{array}$ & $\begin{array}{c}-0.0479 * * \\
(-3.06)\end{array}$ & $\begin{array}{c}-0.0120 \\
(-0.74)\end{array}$ & $\begin{array}{c}-0.0122 \\
(-0.75)\end{array}$ & $\begin{array}{c}-0.0119 \\
(-0.74)\end{array}$ & & & \\
\hline Generator $^{\wedge}$ & & & & & & & $\begin{array}{c}0.259^{*} \\
(2.10)\end{array}$ & $\begin{array}{l}0.190 \\
(1.54)\end{array}$ & $\begin{array}{c}0.320 * * \\
(2.58)\end{array}$ \\
\hline ICT_PCA ${ }^{\wedge \wedge}$ & $\begin{array}{c}0.151 * * * \\
(6.50)\end{array}$ & $\begin{array}{c}0.193 * * * \\
(9.51)\end{array}$ & $\begin{array}{c}0.121 * * * \\
(4.60)\end{array}$ & $\begin{array}{c}0.139 * * * \\
(6.02)\end{array}$ & $\begin{array}{c}0.193 * * * * \\
(9.60)\end{array}$ & $\begin{array}{c}0.107 * * * \\
(4.09)\end{array}$ & $\begin{array}{c}0.144 * * * \\
(6.21)\end{array}$ & $\begin{array}{c}0.199 * * * \\
(9.87)\end{array}$ & $\begin{array}{c}0.109 * * * \\
(4.19)\end{array}$ \\
\hline Gov_PCA ${ }^{\wedge \wedge}$ & $\begin{array}{l}0.011 \\
(0.72)\end{array}$ & $\begin{array}{l}0.017 \\
(1.07)\end{array}$ & $\begin{array}{c}0.0079 \\
(0.50)\end{array}$ & & & & & & \\
\hline Corruption $^{\wedge}$ & & & & $\begin{array}{c}1.153 * * * \\
(5.99)\end{array}$ & $\begin{array}{c}1.033 * * * \\
(5.33)\end{array}$ & $\begin{array}{c}1.157 * * * \\
(6.00)\end{array}$ & $\begin{array}{c}1.421 * * * \\
(6.84)\end{array}$ & $\begin{array}{c}1.237 * * * \\
(5.93)\end{array}$ & $\begin{array}{c}1.479^{* * * *} \\
(7.09)\end{array}$ \\
\hline CrimPol_PCA $^{\wedge \wedge}$ & $\begin{array}{l}0.029 \\
(1.38)\end{array}$ & $\begin{array}{l}0.020 \\
(0.95)\end{array}$ & $\begin{array}{l}0.030 \\
(1.40)\end{array}$ & $\begin{array}{c}0.060 * * \\
(2.97)\end{array}$ & $\begin{array}{c}0.049 * \\
(2.45)\end{array}$ & $\begin{array}{c}0.058 * * \\
(2.87)\end{array}$ & $\begin{array}{c}0.068 * * * \\
(3.36)\end{array}$ & $\begin{array}{c}0.054 * * \\
(2.71)\end{array}$ & $\begin{array}{c}0.068 * * * \\
(3.36)\end{array}$ \\
\hline Comp_PCA ${ }^{\wedge} \wedge$ & $\begin{array}{l}0.0545 \\
(1.49)\end{array}$ & $\begin{array}{c}0.0638 \\
(1.75)\end{array}$ & $\begin{array}{l}0.0587 \\
(1.61)\end{array}$ & $\begin{array}{c}0.0165 \\
(0.46)\end{array}$ & $\begin{array}{c}0.0390 \\
(1.10)\end{array}$ & $\begin{array}{c}0.0195 \\
(0.55)\end{array}$ & $\begin{array}{c}0.00921 \\
(0.26)\end{array}$ & $\begin{array}{c}0.0338 \\
(0.96)\end{array}$ & $\begin{array}{c}0.0113 \\
(0.32)\end{array}$ \\
\hline Intercept & $\begin{array}{c}32.47^{*} \\
(2.28)\end{array}$ & $\begin{array}{l}17.65 \\
(1.23)\end{array}$ & $\begin{array}{c}39.50 * * \\
(2.76)\end{array}$ & $\begin{array}{c}46.65 * * \\
(3.23)\end{array}$ & $\begin{array}{l}26.09 \\
(1.81)\end{array}$ & $\begin{array}{c}54.15 * * * \\
(3.74) \\
\end{array}$ & $\begin{array}{c}56.67 * * * \\
(3.88) \\
\end{array}$ & $\begin{array}{c}33.78^{*} \\
(2.33)\end{array}$ & $\begin{array}{c}67.16 * * * \\
(4.58) \\
\end{array}$ \\
\hline ProbaCRScale & 0,03 & 0,00 & 0,77 & 0,05 & 0,00 & 0,72 & 0,00 & 0,00 & 0,12 \\
\hline 'e K/e L & 0,35 & 0,37 & 0,34 & 0,35 & 0,36 & 0,33 & 0,36 & 0,37 & 0,35 \\
\hline $\mathbf{R}^{2}$ & 0,77 & 0,77 & 0,77 & 0,77 & 0,77 & 0,77 & 0,77 & 0,77 & 0,77 \\
\hline Observations & 5435 & 5435 & 5435 & 5435 & 5435 & 5435 & 5435 & 5435 & 5435 \\
\hline
\end{tabular}

Source: Authors' estimations.

Note: K: capital (in $\log$ ); L: labor (in log); Year: year of survey; Age: firm's age (in years) ; Cert: quality certification; Lic: foreign licensed technology; Export: export status; Foreign_K: foreign ownership of capital; Training: training of employees; Exp. Manager: experience of the top manager (in years); Generator: share/own generator; Corruption: gift when inspected; Infra, ICT, H, Fin, Gov, CrimePol, Comp: investment climate (IC) composite indicators (see Annex 2 for their definition). The expected sign of the IC composite indicators is positive). Variables Age, Cert, Lic, Foreign, Export, Training, Exp. Manager, Generator and Corruption are also expected to have a positive coefficient. Regressions contain country, region and sector fixed-effects. Production functions are estimated by a pool OLS. Heteroskedasticity-robust t-students are reported in parentheses. $* * *, * *, *$, and ${ }^{\prime}$ denote significance at the $0.1 \%, 1 \%, 5 \%$, and $10 \%$ levels, respectively. ${ }^{\wedge}$ Binary variable. ${ }^{\wedge}{ }^{\wedge}$ Aggregated indicator. ${ }^{\wedge} \wedge \wedge$ Business environment variables are replaced by their prediction before entering the composite indicators (see above for details on instrumentation). e K: elasticity of capital ; e L: elasticity of labor; CR: constant returns. 
Table-6a- Production Function with Composite Indicators of

Predicted Value of Business Environment Variables ${ }^{\wedge \wedge}$ : Estimation Results by Sector (1)

(Dependant Variable: Log of Firm Value-Added)

\begin{tabular}{|c|c|c|c|c|c|c|c|c|c|c|}
\hline Sectors & Food & Food & Food & Food & Food & Food & Textile & Garment & Leather & $\begin{array}{c}\text { Wood } \\
\text { Furniture } \\
\end{array}$ \\
\hline $\mathbf{L}$ & $\begin{array}{c}0.742 * * * \\
(14.33)\end{array}$ & $\begin{array}{c}0.706 * * * \\
(12.51)\end{array}$ & $\begin{array}{c}0.758 * * * \\
(15.39)\end{array}$ & $\begin{array}{c}0.723 * * * \\
(13.49)\end{array}$ & $\begin{array}{c}0.742 * * * \\
(13.87)\end{array}$ & $\begin{array}{c}0.709 * * * \\
(12.46)\end{array}$ & $\begin{array}{c}0.746 * * * \\
(8.61)\end{array}$ & $\begin{array}{c}0.797 * * * \\
(15.47)\end{array}$ & $\begin{array}{c}0.806 * * * \\
(8.12)\end{array}$ & $\begin{array}{c}0.981 * * * \\
(13.58)\end{array}$ \\
\hline $\mathbf{K}$ & $\begin{array}{c}0.219^{* * *} \\
(9.02)\end{array}$ & $\begin{array}{c}0.219 * * * \\
(8.98) \\
-\end{array}$ & $\begin{array}{c}0.220^{* * *} \\
(9.07)\end{array}$ & $\begin{array}{c}0.220 * * * \\
(9.02)\end{array}$ & $\begin{array}{c}0.221 * * * \\
(9.12)\end{array}$ & $\begin{array}{c}0.220 * * * \\
(9.08)\end{array}$ & $\begin{array}{c}0.227 * * * \\
(8.28)\end{array}$ & $\begin{array}{c}0.215^{* * *} \\
(9.82)\end{array}$ & $\begin{array}{c}0.164 * * * \\
(5.27)\end{array}$ & $\begin{array}{c}0.194 * * * \\
(6.58)\end{array}$ \\
\hline Year & $\begin{array}{c}-0.043^{* *} \\
(-3.06)\end{array}$ & $\begin{array}{c}0.052 * * * \\
(-3.55)\end{array}$ & $\begin{array}{c}-0.036^{* *} \\
(-2.87)\end{array}$ & $\begin{array}{c}-0.045^{* * *} \\
(-3.43)\end{array}$ & $\begin{array}{c}-0.038^{* *} \\
(-2.86)\end{array}$ & $\begin{array}{c}-0.046^{* * *} \\
(-3.43)\end{array}$ & & & & \\
\hline Age & & & & & & & & $\begin{array}{c}0.004 * * \\
(2.65)\end{array}$ & & \\
\hline QualityCertification`^ & $\begin{array}{c}0.204^{*} \\
(2.41)\end{array}$ & $\begin{array}{c}0.199 * \\
(2.36)\end{array}$ & $\begin{array}{c}0.210 * \\
(2.48)\end{array}$ & $\begin{array}{c}0.206^{*} \\
(2.43)\end{array}$ & $\begin{array}{c}0.204 * \\
(2.41)\end{array}$ & $\begin{array}{c}0.199 * \\
(2.36)\end{array}$ & $\begin{array}{c}0.219 * \\
(2.04)\end{array}$ & $\begin{array}{c}0.241^{* *} \\
(3.17)\end{array}$ & $\begin{array}{l}0.262 * \\
(2.53)\end{array}$ & $\begin{array}{c}0.381 * * * \\
(4.26)\end{array}$ \\
\hline Foreign Lic Tech ${ }^{\wedge}$ & $\begin{array}{l}0.140 \\
(1.49)\end{array}$ & $\begin{array}{l}0.141 \\
(1.51)\end{array}$ & $\begin{array}{l}0.141 \\
(1.50)\end{array}$ & $\begin{array}{l}0.142 \\
(1.52)\end{array}$ & $\begin{array}{l}0.137 \\
(1.45)\end{array}$ & $\begin{array}{l}0.137 \\
(1.46)\end{array}$ & $\begin{array}{l}0.135 \\
(1.24)\end{array}$ & $\begin{array}{l}0.148 \\
(1.68)\end{array}$ & $\begin{array}{l}0.105 \\
(0.94)\end{array}$ & $\begin{array}{c}0.235^{*} \\
(2.14)\end{array}$ \\
\hline $\mathbf{X}^{\wedge}$ & $\begin{array}{c}0.391 * * * \\
(4.88)\end{array}$ & $\begin{array}{c}0.384 * * * \\
(4.81)\end{array}$ & $\begin{array}{c}0.393^{* * * *} \\
(4.89)\end{array}$ & $\begin{array}{c}0.387 * * * \\
(4.81)\end{array}$ & $\begin{array}{c}0.386^{* * * *} \\
(4.83)\end{array}$ & $\begin{array}{c}0.380^{* * * *} \\
(4.76)\end{array}$ & $\begin{array}{c}0.194 * \\
(2.28)\end{array}$ & $\begin{array}{l}0.048, \\
(1.73)\end{array}$ & $\begin{array}{c}0.307 * * * \\
(3.35)\end{array}$ & $\begin{array}{c}0.318 * * * \\
(3.93)\end{array}$ \\
\hline Foreign_K $\mathbf{K}^{\wedge}$ & $\begin{array}{c}0.339 * * * \\
(3.32)\end{array}$ & $\begin{array}{c}0.333^{* *} \\
(3.28)\end{array}$ & $\begin{array}{c}0.341^{* * * *} \\
(3.36)\end{array}$ & $\begin{array}{c}0.336^{* * * *} \\
(3.31)\end{array}$ & $\begin{array}{c}0.336^{* *} \\
(3.29)\end{array}$ & $\begin{array}{c}0.331^{* *} \\
(3.24)\end{array}$ & $\begin{array}{c}0.476^{* * *} \\
(3.49)\end{array}$ & $\begin{array}{r}0.0715 \\
(1.59)\end{array}$ & $\begin{array}{c}0.423^{* *} \\
(2.81)\end{array}$ & $\begin{array}{c}0.350^{* *} \\
(2.89)\end{array}$ \\
\hline Exp. Manager & $\begin{array}{c}0.068^{* * *} \\
(7.42)\end{array}$ & $\begin{array}{c}0.07 * * * \\
(7.65)\end{array}$ & $\begin{array}{c}0.065^{* * * *} \\
(6.55)\end{array}$ & $\begin{array}{c}0.068^{* * *} \\
(6.83)\end{array}$ & $\begin{array}{c}0.064 * * * \\
(5.73)\end{array}$ & $\begin{array}{c}0.065^{* * *} \\
(5.87)\end{array}$ & $\begin{array}{l}0.026 \\
(1.60)\end{array}$ & $\begin{array}{c}0.056 \text { *** } \\
(4.66)\end{array}$ & $\begin{array}{c}0.049^{*} \\
(2.11)\end{array}$ & $\begin{array}{l}\text { 0.024 } \\
(1.63)\end{array}$ \\
\hline Fin_PCA ${ }^{\wedge} \wedge$ & $\begin{array}{c}0.291 * * * \\
(3.73)\end{array}$ & $\begin{array}{c}0.281 * * * \\
(3.68)\end{array}$ & $\begin{array}{c}0.310^{* * * *} \\
(4.33)\end{array}$ & $\begin{array}{c}0.302^{* * *} \\
(4.32)\end{array}$ & $\begin{array}{c}0.325 * * * \\
(4.66)\end{array}$ & $\begin{array}{c}0.316^{* * * *} \\
(4.70)\end{array}$ & $\begin{array}{c}0.469 * * * \\
(5.52)\end{array}$ & $\begin{array}{c}0.500^{* * * *} \\
(8.24)\end{array}$ & $\begin{array}{c}0.459 * * * \\
(5.05)\end{array}$ & $\begin{array}{c}0.348 * * * \\
(4.40)\end{array}$ \\
\hline Infra_PCA ${ }^{\wedge} \wedge$ & $\begin{array}{c}0.095^{* *} \\
(2.76)\end{array}$ & & $\begin{array}{c}0.095^{* *} \\
(2.74)\end{array}$ & & $\begin{array}{c}0.085^{*} \\
(2.49)\end{array}$ & & & & & \\
\hline Generator $^{\wedge}$ & & $\begin{array}{c}0.625 * * \\
(2.82)\end{array}$ & & $\begin{array}{c}0.613^{* *} \\
(2.76)\end{array}$ & & $\begin{array}{c}0.560 * * \\
(2.58)\end{array}$ & $\begin{array}{l}1.238 * * \\
(3.20)\end{array}$ & $\begin{array}{l}0.363 \\
(1.50)\end{array}$ & $\begin{array}{l}1.517 * \\
(2.58)\end{array}$ & $\begin{array}{l}0.374 \\
(1.10)\end{array}$ \\
\hline ICT_PCA ${ }^{\wedge \wedge}$ & $\begin{array}{l}0.106 \\
(1.69)\end{array}$ & $\begin{array}{l}0.106 \\
(1.69)\end{array}$ & & & & & & & & \\
\hline E-mail ${ }^{\wedge}$ & & & $\begin{array}{l}0.387 \\
(1.57)\end{array}$ & $\begin{array}{l}0.370 \\
(1.50)\end{array}$ & & & & & $\begin{array}{l}-0.328 \\
(-0.65)\end{array}$ & $\begin{array}{l}0.816^{*} \\
(2.55)\end{array}$ \\
\hline $\mathbf{W e b}^{\wedge}$ & & & & & $\begin{array}{l}0.384 \\
(1.36)\end{array}$ & $\begin{array}{l}0.395 \\
(1.41)\end{array}$ & $\begin{array}{l}1.244 * * \\
(3.00)\end{array}$ & $\begin{array}{l}0.695^{*} \\
(2.24)\end{array}$ & & \\
\hline Corruption $^{\wedge}$ & $\begin{array}{l}1.14^{*} \\
(2.34)\end{array}$ & $\begin{array}{l}1.19^{*} \\
(2.38)\end{array}$ & $\begin{array}{l}1.07 * \\
(2.21)\end{array}$ & $\begin{array}{l}1.11 * \\
(2.26)\end{array}$ & $\begin{array}{l}1.06^{*} \\
(2.20)\end{array}$ & $\begin{array}{l}1.11^{*} \\
(2.24)\end{array}$ & $\begin{array}{l}1.42 * \\
(2.51)\end{array}$ & $\begin{array}{l}1.01 * * \\
(2.63)\end{array}$ & $\begin{array}{c}-0.92 \\
(-0.85)\end{array}$ & $\begin{array}{c}2.95 * * * \\
(4.86)\end{array}$ \\
\hline${\text { CrimPol_PCA }{ }^{\wedge} \wedge}^{\wedge}$ & $\begin{array}{c}0.286^{* * * *} \\
(3.83)\end{array}$ & $\begin{array}{c}0.259 * * * \\
(3.54)\end{array}$ & $\begin{array}{c}0.281 * * * \\
(3.78)\end{array}$ & $\begin{array}{c}0.252 * * * \\
(3.47)\end{array}$ & $\begin{array}{c}0.264 * * * \\
(3.64)\end{array}$ & $\begin{array}{c}0.240 * * * \\
(3.37)\end{array}$ & & & & \\
\hline $\begin{array}{l}\text { Roberies }^{\wedge} \\
\text { Comp } \mathrm{PCA}^{\wedge} \wedge\end{array}$ & & & & & & & $\begin{array}{l}1.242 * * \\
(2.96)\end{array}$ & $\begin{array}{c}0.46 \\
(1.49)\end{array}$ & $\begin{array}{c}-0.40 \\
(-0.53)\end{array}$ & $\begin{array}{c}0.719 * \\
(1.90)\end{array}$ \\
\hline $\begin{array}{l}\text { Comp_PCA^^}{ }^{\wedge} \\
\text { Market Size }^{\wedge}\end{array}$ & & & & & & & $\begin{array}{c}1.124 * * \\
(3.10)\end{array}$ & $\begin{array}{c}0.902 * * * \\
(3.30)\end{array}$ & $\begin{array}{c}1.521 * * * \\
(3.67)\end{array}$ & $\begin{array}{c}1.203 * * * \\
(3.94)\end{array}$ \\
\hline Intercept & $\begin{array}{c}91.8^{* *} \\
(3.26) \\
\end{array}$ & $\begin{array}{c}109.5 * * * \\
(3.75)\end{array}$ & $\begin{array}{l}77.7 * * \\
(3.10) \\
\end{array}$ & $\begin{array}{c}94.5^{* * * *} \\
(3.65) \\
\end{array}$ & $\begin{array}{c}80.9^{* *} \\
(3.08) \\
\end{array}$ & $\begin{array}{c}97.0 * * * \\
(3.64)\end{array}$ & $\begin{array}{l}3.9 * * * \\
(5.73) \\
\end{array}$ & $\begin{array}{l}5.6^{* * * *} \\
(11.08) \\
\end{array}$ & $\begin{array}{c}7.6^{* * * *} \\
(8.97) \\
\end{array}$ & $\begin{array}{l}2.2^{* *} \\
(3.15) \\
\end{array}$ \\
\hline $\begin{array}{l}\text { Proba CRScale } \\
\text { 'e K/e L }\end{array}$ & $\begin{array}{l}0.38 \\
0,30\end{array}$ & $\begin{array}{l}0,13 \\
0,31\end{array}$ & $\begin{array}{l}0,58 \\
0,29\end{array}$ & $\begin{array}{l}0,21 \\
0,30\end{array}$ & $\begin{array}{l}0,42 \\
0,30\end{array}$ & $\begin{array}{l}0,16 \\
0,31\end{array}$ & $\begin{array}{l}0,72 \\
0.30\end{array}$ & $\begin{array}{l}0,83 \\
0,27\end{array}$ & $\begin{array}{l}0,76 \\
0,20\end{array}$ & $\begin{array}{l}0,01 \\
0,20\end{array}$ \\
\hline $\mathbf{R}^{2}$ & 0,76 & 0,76 & 0,76 & 0,76 & 0,76 & 0,76 & 0,78 & 0,82 & 0,83 & 0,84 \\
\hline Observations & 1542 & 1542 & 1542 & 1542 & 1542 & 1542 & 858 & 1273 & 540 & 834 \\
\hline
\end{tabular}


Table-6b- Production Function with Composite Indicators of Predicted Value of Business Environment Variables $^{\wedge \wedge \wedge}$ : Estimation Results by Sector (1) (Dependant Variable: Log of Firm Value-Added)

\begin{tabular}{|c|c|c|c|c|c|c|c|c|c|}
\hline Sectors & $\begin{array}{l}\text { Rubber } \\
\text { Plastic }\end{array}$ & $\begin{array}{l}\text { Chemicals } \\
\text { Petroleum }\end{array}$ & $\begin{array}{c}\text { NonMetal } \\
\text { BasicMetal }\end{array}$ & $\begin{array}{c}\text { Metal } \\
\text { Products }\end{array}$ & Machinery & Transport & $\begin{array}{c}\text { Manuf } \\
\text { Tot }\end{array}$ & $\begin{array}{c}\text { Manuf } \\
\text { Tot }\end{array}$ & $\begin{array}{c}\text { Manuf } \\
\text { Tot }\end{array}$ \\
\hline $\mathbf{L}$ & $\begin{array}{c}0.836^{* * * *} \\
(12.06)\end{array}$ & $\begin{array}{c}0.729 * * * \\
(13.12)\end{array}$ & $\begin{array}{c}0.763 * * * \\
(10.35)\end{array}$ & $\begin{array}{c}0.901 * * * \\
(12.39)\end{array}$ & $\begin{array}{c}0.917 * * * \\
(14.80)\end{array}$ & $\begin{array}{c}0.960 * * * \\
(11.94)\end{array}$ & $\begin{array}{c}0.714 * * * \\
(26.96)\end{array}$ & $\begin{array}{c}0.736 * * * \\
(26.75)\end{array}$ & $\begin{array}{c}0.719 * * * \\
(25.18)\end{array}$ \\
\hline $\mathbf{K}$ & $\begin{array}{c}0.190 * * * \\
(7.14)\end{array}$ & $\begin{array}{c}0.186^{* * * *} \\
(9.08)\end{array}$ & $\begin{array}{c}0.209 * * * \\
(7.61)\end{array}$ & $\begin{array}{c}0.196 * * * \\
(6.61)\end{array}$ & $\begin{array}{c}0.137 * * * \\
(4.00)\end{array}$ & $\begin{array}{c}0.126^{* * * *} \\
(4.78)\end{array}$ & $\begin{array}{c}0.247 * * * \\
(20.08)\end{array}$ & $\begin{array}{c}0.250 * * * \\
(20.19)\end{array}$ & $\begin{array}{c}0.252 * * * \\
(20.56)\end{array}$ \\
\hline Year & & & & & & & $\begin{array}{c}-0.031 * * * \\
(-4.18)\end{array}$ & $\begin{array}{l}-0.019 * \\
(-2.47)\end{array}$ & $\begin{array}{c}-0.021 * * \\
(-2.69)\end{array}$ \\
\hline Age & & & $\begin{array}{l}-0.004 * \\
(-2.22)\end{array}$ & & & & $\begin{array}{l}0.001 \\
(1.35)\end{array}$ & $\begin{array}{l}0.001 \\
(1.39)\end{array}$ & $\begin{array}{l}0.001 \\
(1.16)\end{array}$ \\
\hline QualityCertification $^{\wedge}$ & $\begin{array}{c}0.399 * * * \\
(4.22)\end{array}$ & $\begin{array}{l}0.127 \\
(1.82)\end{array}$ & $\begin{array}{c}0.308^{* *} \\
(3.21)\end{array}$ & $\begin{array}{c}0.197 * \\
(2.18)\end{array}$ & $\begin{array}{c}0.314 * * * \\
(3.75)\end{array}$ & $\begin{array}{c}0.280 * * \\
(3.09)\end{array}$ & $\begin{array}{c}0.207 * * * \\
(4.90)\end{array}$ & $\begin{array}{c}0.216^{* * *} \\
(5.09)\end{array}$ & $\begin{array}{c}0.207 * * * \\
(4.87)\end{array}$ \\
\hline Foreign Lic Tech $^{\wedge}$ & $\begin{array}{c}0.249 * \\
(2.25)\end{array}$ & $\begin{array}{c}0.0405 \\
(0.48)\end{array}$ & $\begin{array}{l}0.238^{*} \\
(2.19)\end{array}$ & $\begin{array}{l}0.128 \\
(1.28)\end{array}$ & $\begin{array}{c}0.189 * \\
(2.07)\end{array}$ & $\begin{array}{l}0.166 \\
(1.61)\end{array}$ & $\begin{array}{c}0.129 * * \\
(2.88)\end{array}$ & $\begin{array}{c}0.140 * * \\
(3.13)\end{array}$ & $\begin{array}{c}0.137 * * \\
(3.04)\end{array}$ \\
\hline $\mathbf{X}^{\wedge}$ & $\begin{array}{l}0.206^{*} \\
(2.30)\end{array}$ & $\begin{array}{c}0.360 * * * \\
(5.19)\end{array}$ & $\begin{array}{c}-0.0878 \\
(-0.95)\end{array}$ & $\begin{array}{c}0.0701 \\
(0.88)\end{array}$ & $\begin{array}{c}0.229 * * \\
(3.20)\end{array}$ & $\begin{array}{c}0.217 * * \\
(2.67)\end{array}$ & $\begin{array}{c}0.185 * * * \\
(5.04)\end{array}$ & $\begin{array}{c}0.190 * * * \\
(5.17)\end{array}$ & $\begin{array}{c}0.186^{* * * *} \\
(5.08)\end{array}$ \\
\hline Foreign_K^ ${ }^{\wedge}$ & $\begin{array}{c}0.479 * * * \\
(3.61)\end{array}$ & $\begin{array}{c}0.421 * * * \\
(4.49)\end{array}$ & $\begin{array}{c}0.552 * * * \\
(4.44)\end{array}$ & $\begin{array}{c}0.297 * \\
(2.42)\end{array}$ & $\begin{array}{c}0.445^{* * *} \\
(3.53)\end{array}$ & $\begin{array}{c}0.535^{* * * *} \\
(3.55)\end{array}$ & $\begin{array}{c}0.320 * * * \\
(6.26)\end{array}$ & $\begin{array}{c}0.291 * * * \\
(5.74)\end{array}$ & $\begin{array}{c}0.293 * * * \\
(5.78)\end{array}$ \\
\hline Exp. Manager & $\begin{array}{c}0.038 * \\
(2.03)\end{array}$ & $\begin{array}{l}0.03^{*} \\
(2.42)\end{array}$ & $\begin{array}{c}0.065^{* * * *} \\
(4.43)\end{array}$ & $\begin{array}{c}0.053^{* *} \\
(3.20)\end{array}$ & $\begin{array}{l}0.024 \\
(1.85)\end{array}$ & $\begin{array}{c}0.052^{*} \\
(2.51)\end{array}$ & $\begin{array}{c}0.036^{* * *} \\
(6.70)\end{array}$ & $\begin{array}{c}0.038^{* * *} \\
(7.84)\end{array}$ & $\begin{array}{c}0.038 * * * \\
(6.86)\end{array}$ \\
\hline Fin_PCA ${ }^{\wedge} \wedge$ & $\begin{array}{c}0.298 * * \\
(2.76)\end{array}$ & $\begin{array}{c}0.353 * * * \\
(6.30)\end{array}$ & $\begin{array}{c}0.306^{* *} \\
(2.75)\end{array}$ & $\begin{array}{c}0.0542 \\
(0.52)\end{array}$ & $\begin{array}{c}0.360 * * * \\
(6.20)\end{array}$ & $\begin{array}{c}0.214 * * \\
(2.75)\end{array}$ & $\begin{array}{c}0.233 * * * \\
(8.38)\end{array}$ & $\begin{array}{c}0.276^{* * * *} \\
(10.47)\end{array}$ & $\begin{array}{c}0.276^{* * * *} \\
(10.38)\end{array}$ \\
\hline Infra_PCA ${ }^{\wedge \wedge}$ & & & & & & & & & \\
\hline Generator $^{\wedge}$ & $\begin{array}{l}-0.501 \\
(-1.28)\end{array}$ & $\begin{array}{c}1.146^{* * * *} \\
(3.63)\end{array}$ & $\begin{array}{l}0.644 \\
(1.81)\end{array}$ & $\begin{array}{l}0.552 \\
(1.20)\end{array}$ & $\begin{array}{l}-0.200 \\
(-0.63)\end{array}$ & $\begin{array}{c}1.175^{* *} \\
(2.82)\end{array}$ & $\begin{array}{c}0.320^{* *} \\
(2.58)\end{array}$ & $\begin{array}{c}0.290 * \\
(2.24)\end{array}$ & $\begin{array}{c}0.250 * \\
(1.96)\end{array}$ \\
\hline ICT_PCA ${ }^{\wedge} \wedge$ & & & $\begin{array}{c}0.215^{* *} \\
(2.66)\end{array}$ & & & $\begin{array}{c}0.156^{*} \\
(2.01)\end{array}$ & $\begin{array}{c}0.109^{* * *} \\
(4.19)\end{array}$ & & \\
\hline E-mail^^ & $\begin{array}{c}1.437 * * \\
(3.01)\end{array}$ & $\begin{array}{l}0.482 \\
(1.33)\end{array}$ & & $\begin{array}{c}1.191 * * \\
(3.06)\end{array}$ & $\begin{array}{l}0.462 \\
(1.02)\end{array}$ & & & $\begin{array}{c}0.322 * * \\
(2.80)\end{array}$ & \\
\hline $\mathbf{W e b}^{\wedge}$ & & & & & & & & & $\begin{array}{c}0.355^{*} \\
(2.43)\end{array}$ \\
\hline Corruption $^{\wedge}$ & $\begin{array}{c}1.917 * * \\
(2.60)\end{array}$ & $\begin{array}{c}2.149 * * \\
(3.17)\end{array}$ & $\begin{array}{c}1.173^{*} \\
(1.90)\end{array}$ & $\begin{array}{c}2.419 * * * \\
(4.62)\end{array}$ & $\begin{array}{c}3.144 * * * \\
(3.78)\end{array}$ & $\begin{array}{l}5.65^{*} \\
(2.37)\end{array}$ & $\begin{array}{c}1.479 * * * \\
(7.09)\end{array}$ & $\begin{array}{c}1.314^{* * * *} \\
(6.67)\end{array}$ & $\begin{array}{c}1.289 * * * \\
(6.37)\end{array}$ \\
\hline CrimPol_PCA $^{\wedge} \wedge$ & & $\begin{array}{c}0.120 * \\
(2.26)\end{array}$ & & & & & $\begin{array}{c}0.0683 * * * \\
(3.36)\end{array}$ & & \\
\hline Roberies $^{\wedge}$ & $\begin{array}{l}0.597 \\
(1.13)\end{array}$ & & & $\begin{array}{c}0.888 * \\
(1.95)\end{array}$ & & $\begin{array}{c}3.079 * * \\
(2.88)\end{array}$ & & $\begin{array}{l}0.065 \\
(0.45)\end{array}$ & $\begin{array}{l}-0.005 \\
(-0.03)\end{array}$ \\
\hline Comp_PCA ${ }^{\wedge} \wedge$ & $\begin{array}{l}-0.091 \\
(-1.08)\end{array}$ & & $\begin{array}{l}0.177 \\
(1.57)\end{array}$ & & & & $\begin{array}{l}0.011 \\
(0.32)\end{array}$ & & \\
\hline Market Size $^{\wedge}$ & & & & & & $\begin{array}{l}0.837 \\
(1.73)\end{array}$ & & $\begin{array}{l}0.128 \\
(0.83)\end{array}$ & $\begin{array}{l}0.120 \\
(0.75)\end{array}$ \\
\hline Intercept & $\begin{array}{c}3.87 * * * \\
(4.19)\end{array}$ & $\begin{array}{c}5.36^{* * * *} \\
(7.08)\end{array}$ & $\begin{array}{c}6.21 * * * \\
(8.13)\end{array}$ & $\begin{array}{c}2.96^{* * * *} \\
(3.63)\end{array}$ & $\begin{array}{c}4.55^{* * *} \\
(5.05)\end{array}$ & $\begin{array}{c}-1.07 \\
(-0.42) \\
\end{array}$ & $\begin{array}{c}67.2 * * * \\
(4.58)\end{array}$ & $\begin{array}{l}43.2^{* * *} \\
(2.84)\end{array}$ & $\begin{array}{l}47.2 * * \\
(3.08)\end{array}$ \\
\hline ProbaCRScale & 0,68 & 0,85 & 0,66 & 0,16 & 0,27 & 0,24 & 0,10 & 0,57 & 0,24 \\
\hline ‘e K/ e L & 0,23 & 0,26 & 0,27 & 0,22 & 0,15 & 0,13 & 0,35 & 0,34 & 0,35 \\
\hline $\mathbf{R}^{2}$ & 0,80 & 0,80 & 0,81 & 0,80 & 0,81 & 0,85 & 0,74 & 0,77 & \\
\hline Observations & 660 & 948 & 744 & 714 & 691 & 485 & 5435 & 5484 & 5484 \\
\hline
\end{tabular}

Source: Authors' estimations. For Table 6a and 6b.

Note: K: capital (in log); L: labor (in log); Year: year of survey; Age: firm's age (in years) ; Cert: quality certification; Lic: foreign licensed technology; Export: export status; Foreign_K: foreign ownership of capital; Exp. Manager: experience of the top manager (in years); Generator: share/own generator; Email \& Web: access to e-mail and internet; Corruption ${ }^{\wedge}$ : gift when inspected; Roberies: losses due to robberies; Market Size: local, national or international; Infra, ICT, H, Fin, Gov, CrimePol, Comp: investment climate (IC) composite indicators (see Annex 2 for their definition). The expected sign of the IC composite indicators is positive). Variables Age, Cert, Lic, Foreign, Export, Training, Exp. Manager, Generator and Corruption are also expected to have a positive coefficient. Regressions contain country, region and sector fixed-effects. Production functions are estimated by a pool OLS Heteroskedasticity-robust t-students are reported in parentheses. $* * *, * *, *$, and ${ }^{*}$ denote significance at the $0.1 \%, 1 \%, 5 \%$, and $10 \%$ levels, respectively. ${ }^{\wedge}$ Binary variable. 
$\wedge^{\wedge}$ Aggregated indicator. ${ }^{\wedge \wedge}$ Business environment variables are replaced by their prediction before entering the composite indicators. e K: elasticity of capital ; e L: elasticity of labor; CR: constant returns.

also to be robust to the different specifications tested above. In the end, it is reassuring to discover that the most convincing results in terms of technology of production, and the role of the business environment, are obtained when addressing in a more rigorous way data limitation problems and endogeneity issues.

As for firm characteristics, especially foreign orientation, this new set of regressions confirms the previous findings. Quality certification (Cert), foreign license technology ( Lic), export status (Export) and foreign presence in capital (Foreign) contribute, often more strongly, and with more significance than previously, to firm performance (depending on the sector).

Looking at the sector level reveals differences across industries. For some sectors, the results are poorer than for others. This is true for Leather and, to a lesser extent, for some heavy industries for which the number of observations is small. As noted since the beginning of the paper, heavy industries are more difficult to work on. This may be linked to the quality of the data and/or the sample size. This stresses once again the importance of addressing data limitation issues.

Furthermore, industries seem to be affected differently by the various dimensions of the business environment. The impact of human capacity $(\mathrm{H})$ is strong in Agro-Processing and Non Basic Metal, and to a lesser extent, in Garment, Transport and Metal Products. Financing constraints (Fin) appear to hinder more firms' performance in Textile, Garment, Leather and Metal Products. Conclusions are more difficult to draw in the case of traditional infrastructure (Infra) which looks however to play a more substantial role in Textile, Leather and Chemicals. ICT appears to be significant in Textile and in most heavy industries. As for government relation (Gov), corruption (Corr) more specifically, heavy industries seem to be more affected than others.

The same conclusions can be drawn for the outward orientation of the firms, with quality certification (Cert) being an important factor of performance in all sectors, especially in heavy industries, and also foreign participation in firms' capital (Foreign). Export orientation (Export) appears to be a constant advantage in almost all sectors, with firms in Agro-Processing benefiting the most from access to world markets. Foreign license technology ( $\mathrm{Lic}$ ) is a less constant factor in boosting firm performance, except in some heavy industries. This seems to be due to the higher technological content of these industries.

To summarize the main findings by industry, Agro-Processing would benefit from improvements of all dimensions of the business environment (except competition (Comp)), and of its outward orientation, with a special attention to the quality of its labor force $(H)$ and to its export orientation (Export). The same conclusions can be drawn for Textile, with a higher sensitivity to financing (Fin), infrastructure (Infra), and ICT. Financing (Fin) and human capacity $(H)$ are particularly important to Garment, although infrastructure (Infra) and security and political stability (CrimePol) do not seem to be of major importance to it. As already mentioned, firm performance in the Leather industry does not seem to be affected by ICT, government relations (Gov), and security and political stability (CrimePol), but is more affected by traditional infrastructure deficiencies (Infra), financing 
constraints (Fin) and competition (Comp), like the 2 other exporting light industries (Garment and Textile).

For heavy industries, although it is more difficult than in the case of light industries to confirm the importance of almost all business environment variables (with more difficulty for competition (Comp) and infrastructure (Infra)), human capacity $(H), I C T$, government relation (Gov) (corruption (Corr) especially) and, with less strength than for light industries, financing constraints (Fin) appear to hinder firm performance. This is not a surprise as these industries need more skills and modern communication technologies to operate.

In conclusion, light industries appear to be more sensitive to more dimensions of the business environment (financing (Fin), human capacity $(H)$, infrastructure (Infra), and competition (Comp) in particular). This fragility may be due to the fact that most of these industries face international competition and need a supportive environment to compete efficiently. This means that the benefit of an improvement of the business environment would be more substantial in these sectors, which could play a leading role in the industrial development and export capacity of the economy. This conclusion is all the more important for the countries specialized in light manufacturing. Improving investment climate in these sectors is necessary in the face of strong international competition. Moreover, it would reinforce the growth and the catch-up process of these economies. As for heavy industries, although less sensitive to fewer dimensions of their environment, they would benefit from an improvement in several fields (human capacity $(H), I C T$, government relation (Gov) and, with less strength financing (Fin), as well as from an increase of its foreign exposure.

\subsubsection{Treating Endogeneity (2): Using the Time Dimension of the Investment Climate Variables}

Our last set of regressions addresses endogeneity by using the time dimension of the investment climate variables. Endogenous independent variables of the second survey are instrumented by their lag value, that of the first survey. Secondly, to correct for error measurements, this lag value is replaced by its same year prediction, as explained before ${ }^{21}$. New composite investment climate indicators take into consideration these 2 changes. Equation (4) is estimated for the same panel of countries, but for the second year surveyed only. As the sample size is reduced by a factor of 3 , we end up with a very small number of observations in some sectors. This makes comparisons with the results by sector in the previous section quite difficult. The findings are therefore presented at the aggregate level only, for the manufacturing sector as a whole (Table 7).

The first conclusion concerns the technology of production. Its estimation is again improved in this new specification. The capital/labor ratio is in line with the literature, and the constant returns to scale are well validated by the data. These results support our previous conclusions regarding a possible bias in our first 2 specifications. They confirm that addressing data issues and using a pertinent statistical approach provides less biased estimation results. In addition, sectors and regions fixed-effects still contribute to the observed differences in firm-level productivity.

\footnotetext{
${ }^{21}$ It is this specification that will be presented here, because results give more satisfaction.
} 
The conclusions regarding the contribution of the investment climate indicators are also reinforced in this new set of regressions. Almost all dimensions of firm business environment still contribute to firm productivity with approximatively the same strength, except security and political stability ( $\mathrm{CrimePol}$ ), and government relation (Gov) whose role is no longer validated by the data. These 2 dimensions of

Table-7- Production Function with Composite Indicators of Predicted Value of Business Environment Variables ${ }^{\wedge} \wedge \wedge$ : Estimation Results

(Dependant Variable: Log of Firm Value-Added)

\begin{tabular}{|c|c|c|}
\hline Manufacturing & (1) & (1') \\
\hline $\mathbf{L}$ & $\begin{array}{c}0.747 * * * \\
(20.99)\end{array}$ & $\begin{array}{c}0.745^{* * *} * \\
(20.95)\end{array}$ \\
\hline $\mathbf{K}$ & $\begin{array}{c}0.256 * * * \\
(12.63)\end{array}$ & $\begin{array}{c}0.258 * * * \\
(12.75)\end{array}$ \\
\hline Quality Certification $^{\wedge}$ & $\begin{array}{l}0.112 \\
(1.57)\end{array}$ & $\begin{array}{l}0.120 \\
(1.68)\end{array}$ \\
\hline Foreign Lic Tech ${ }^{\wedge}$ & $\begin{array}{l}0.023 \\
(0.28)\end{array}$ & $\begin{array}{l}0.024 \\
(0.29)\end{array}$ \\
\hline $\mathbf{x}^{\wedge}$ & $\begin{array}{c}0.144 * \\
(2.19)\end{array}$ & $\begin{array}{c}0.135 * \\
(2.04)\end{array}$ \\
\hline Foreign_K${ }^{\wedge}$ & $\begin{array}{c}0.372 * * * \\
(4.07)\end{array}$ & $\begin{array}{c}0.368 * * * \\
(4.04)\end{array}$ \\
\hline $\mathbf{H}_{-} \mathbf{P C A}{ }^{\wedge \wedge}$ & $\begin{array}{c}0.091 * * \\
(3.08)\end{array}$ & \\
\hline Training $^{\wedge}$ & & $\begin{array}{c}0.523 * * \\
(2.75)\end{array}$ \\
\hline Fin_PCA ${ }^{\wedge \wedge}$ & $\begin{array}{c}0.257 * * * \\
(6.71)\end{array}$ & $\begin{array}{c}0.258 * * * \\
(6.78)\end{array}$ \\
\hline Power ${ }^{\wedge}$ & $\begin{array}{c}0.480^{*} \\
(2.25)\end{array}$ & $\begin{array}{c}0.462 * \\
(2.17)\end{array}$ \\
\hline ICT_PCA $^{\wedge \wedge}$ & $\begin{array}{c}0.179 * * * \\
\quad(6.05)\end{array}$ & $\begin{array}{c}0.177 * * * \\
(6.04)\end{array}$ \\
\hline Corruption $^{\wedge}$ & $\begin{array}{l}0.691 \\
(0.86)\end{array}$ & $\begin{array}{c}0.565 \\
(0.70)\end{array}$ \\
\hline CrimPol_PCA $^{\wedge \wedge}$ & $\begin{array}{l}0.011 \\
(0.33)\end{array}$ & $\begin{array}{l}0.014 \\
(0.41)\end{array}$ \\
\hline Comp_PCA ${ }^{\wedge \wedge}$ & $\begin{array}{c}0.066^{*} \\
(2.32)\end{array}$ & $\begin{array}{c}0.064 * \\
(2.26)\end{array}$ \\
\hline Intercept & $\begin{array}{c}7.11 * * * \\
(9.17)\end{array}$ & $\begin{array}{c}7.02 * * * \\
(9.07)\end{array}$ \\
\hline $\begin{array}{l}\text { Prob CRScale } \\
\text { 'e K/e L } \\
\mathbf{R}^{2} \\
\text { Observations }\end{array}$ & $\begin{array}{l}0,92 \\
0,34 \\
0,75 \\
\mathbf{1 8 5 2}\end{array}$ & $\begin{array}{l}0,91 \\
0,35 \\
0,75 \\
\mathbf{1 8 6 5}\end{array}$ \\
\hline
\end{tabular}

Source: Authors' estimations.

Note: K: capital (in log); L: labor (in log); Cert: quality certification; Lic: foreign licensed technology; Export: export status; Foreign_K: foreign ownership of capital; Training: training of employees; Power: power shortages; Corruption: gift when inspected; Infra, ICT, H, Fin, Gov, CrimePol, Comp: investment climate (IC) composite indicators (see Annex 2 for their definition). The expected sign of the IC composite indicators is positive. Variables Age, Cert, Lic, Foreign, Export, Training, Power and Corruption are also expected to have a positive coefficient. Regressions contain country, region and sector fixedeffects. Production functions are estimated by a pool OLS. Heteroskedasticity-robust t-students are reported in parentheses. ***, $* *, *$, and ' denote significance at the $0.1 \%, 1 \%, 5 \%$, and $10 \%$ levels, respectively. ${ }^{\wedge}$ Binary variable. ${ }^{\wedge} \wedge$ Aggregated indicator. $\wedge \wedge \wedge$ Business environment variables are instrumented by the lag value of their prediction before entering the composite indicators (see above for details on instrumentation). e K: elasticity of capital ; e L: elasticity of labor; CR: constant returns. 
the investment climate have already been revealed to be more sensitive to sample size, which may explain the present finding. Nevertheless, skill and experience of the labor force $(H)$, financing capacity (Fin), quality of infrastructure (Infra), access to ICT, and competition (Comp) appear robust to the change in specification.

These new estimations also confirm the positive role of an outward orientation as a means of boosting firm productivity, competitiveness, and economic growth, because all dimensions of foreign exposure, except foreign licensed technology (Lic), are still significant.

In conclusion, although comparisons prove to be difficult due to the big reduction in the number of observations, this last correction of endogeneity does not contradict our previous findings, and so reinforces our conclusions about the important role of almost all dimensions of the business environment for firm productive performance.

\section{7- Conclusion}

In this paper, we use advanced econometric techniques to overcome endogeneity and other data limitation issues, when testing the link between investment climate and firm-level productivity. Using predictions of potentially endogenous variables, as well as the time dimension of the WBES database, which is available for a growing number of economies, we make a contribution to the empirical literature by validating this link in a more rigorous way than in previous studies, for more dimensions of the business environment, and on a wider sample of industries and countries.

Our results confirm that improving infrastructure quality (Infra), access to financing (Fin), use of information and communication technologies $(I C T)$, skills and expertise of the labor force $(H)$, and to a lesser extent, government relations (Gov), competition (Comp), security and political stability (CrimePol) are important factors in firm performance. This finding shows that, in the global economy where technology diffuses rapidly, and capital is mobile, the persistence of firm-level productivity differences between countries can be explained by differences in the business environment. This conclusion is important for developing economies, where the deficiencies of the investment climate can explain why firm-level productivity often lags behind. In addition, our empirical work highlights the productive role of firms' foreign exposure through, in particular, exporting (Export), foreign participation in capital (Foreign), quality certification (Cert), and foreign licensed technology (Lic).

As for policy implications, our findings are useful to show what determinants of productivity cause producers to be better performers, and where reform should be targeted to have the greatest impact on productivity. Building on these dimensions would have a large payoff for the productivity and the competitiveness of the manufacturing industry as a whole. This factor should be kept in mind when dealing with the reform agenda of many developing countries, where the deficiencies appear high in some dimensions of the investment climate. Enhancement of these dimensions would contribute to catching up with emerging and more developed economies.

A more in-depth analysis reveals interesting differences between industries. Although the sectors' performances depend on different dimensions of the investment climate, firms in light industries 
appear to be more sensitive to more dimensions of the business environment (financing (Fin), human capacity $(H)$, infrastructure (Infra), and competition (Comp) in particular). This may be due to the fact that firms in these industries face international competition and need a supportive investment climate to compete efficiently. This fragility requires that particular attention be paid when taking decisions that may affect these sectors. This also means that the payoff of an improvement of the investment climate (in terms of productive performance and competitiveness) would be more substantial in these sectors, which could play a greater role in the industrial development and the export capacity of the developing world. This result constitutes an important way to understand the positive impact of investment climate since manufacturing in the developing world faces competition in the world market.

As for heavy industries, although less sensitive to fewer dimensions of their environment, they would nevertheless particularly benefit from an improvement in several of its dimensions (human capacity $(H)$, information and communication technologies (ICT), relation with the government (Gov), corruption (Corr) in particular and, to a lesser extent, financing (Fin)), as well as from an increase in their outward orientation.

Developing economies are increasingly concerned about improving productivity and competitiveness, because they are experiencing a poor integration into the world economy and the intensifying pressure of globalization. This is particularly true for light industries, in which export specialization is high in the developing world. But heavy industries are also important in the perspective of diversifying the economies. The World Bank Enterprise Surveys (WBES) provide a standard instrument for identifying key obstacles to productivity and so to prioritize policy reforms. This instrument can be used to boost growth and competitiveness, as well as to achieve more technologically advanced and diversified specializations. These factors should be taken into consideration if developing economies want to face the increasing competition of countries which have successfully developed and diversified their economy. Targeting reforms on those industries and investment climate variables which are the worst and which most favor productivity could constitute an important element in the strategy of growth and employment for the future.

\section{References}

Acemoglu, D. and Shimer, R. 1999. Efficient Unemployment Insurance. Journal of Political Economy, 107(5):893-928.

Acemoglu, D., Johnson, S. and Robinson J.A. 2001. The Colonial Origins of Comparative Development: An Empirical Investigation, American Economic Review, 91(5):1369-401.

Aghion, P. and Griffith, R. 2005. Competition and Growth-Reconciling Theory and Evidence, Cambridge: MIT Press.

Aghion, P. 2012. Growth Policy and the State, Working Paper 3, the Growth Dialogue: Washington, D.C. 
Alesina, A., Ozler, S., Roubini, N. and Swagel, P. 1996. Political instability and economic growth, Journal of Economic. Growth 1(2): 189-211.

Amin, M. 2009. Crime, Security and Firms in Latin America, Small Note, The World Bank: Washington, D.C.. http://works.bepress.com/mohammad_amin/11/

Argimon, I., Gonzales-Paramo, J. M. and Hernández de Cos, P. 1997. Evidence of Public Spending CrowdingOut from a Panel of OECD Countries, Applied Economics, 2, 1001-10.

Aschauer, D.A. 1989. Is Public Expenditure Productive? Journal of Monetary Economics, 23:177-200.

Aterido. R. and Hallward-Driemeier, M. 2007. Impact of Access to Finance, Corruption and Infrastructure on Employment Growth (07/21/2008).

Aterido, R., Hallward-Driemeier, M. and Pages, C. 2011. Big Constraints to Small Firms'Growth? Business Environment and Employment Growth across Firms. Economic Development and Cultural Change, 59(3): 609647.

Balassa, B. 1978. Exports and Economic Growth: Further Evidence. The World Bank, Washington, D.C.

Balassa, B. 1988, Outward orientation, in Chenery, H.B. and Srinivasan, T.N. (eds), Handbook of Development Economics, Vol. 2, North-Holland, Amsterdam.

Barron, D. N., West, E. and Hannan, M. T. 1994. A Time to Growth and a Time to Die: Growth and Mortality of Credit Unions in New York, 1914-1990. American Journal of Sociology 100 (2): 381-421.

Barro, R. J. 1997. Determinants of Economic Growth, MIT Press, Cambridge MA.

Basant, R. and Fikkert, B. 1996. The effects of R\&D, Foreign Technology Purchase, and Domestic and International Spillovers on Productivity in Indian Firms, Review of Economics \& Statistics, 78, 187-199.

Bastos, F. and Nasir, J. 2004. Productivity and Investment Climate: What Matters Most? World Bank Policy Research Paper 3335. The World Bank, Washington, D.C..

Beck, T., Demirguc-kunt, A. and Maksimovi, V. 2005. Financial and Legal Constraints to Growth: Does firm Size Matter? The Journal of Finance LX (I):137-177.

BenYishay, A. 2014. Crime and Microenterprise Growth: Evidence from Mexico, World Development 56 (April):139-152

Bernard, A.B. and Jensen, J.B. 2004. Exporting and productivity in the USA, Oxford Review of Economic Policy, 20, 343-57.

Blejer, M.I and Kahn, M.S. 1984. Government Policy and Private Investment in Developing Countries, IMF Staff Papers. 31. IMF: Washington, D.C..

Borensztein, E., De Gregorio, J. and Lee, J-W. 1998. How Does Foreign Direct Investment Affect Economic Growth? NBER Working Paper 5057

Branstetter, L.G. and Chen, J.R. 2006. The Impact of Technology Transfer and R\&D on Productivity Growth in Taiwanese Industry: Micro Econometric Analysis Using Plant and Firm-Level Data, Journal of the Japanese and International Economies, 20, 177-192. 
Bresnahan, T., Brynjolfsson, E. and Hitt, L. 2002. Information Technology, Workplace Organization and the Demand for Skilled Labour: Firm-level Evidence, Quarterly Journal of Economics, 117: 339-376.

Carlin, W., Schaffer, M.E. and Seabright, P. 2006. Where are the Real Bottlenecks? A Langrangian Approach to Identifying Constraints on Growth from Subjective Survey Data. CERT Discussion Paper 2006/04. Centre for Economic Reform and Transformation, Edinburgh.

Chaffai, M., Kinda, T. and Plane, P. 2014. Textile Manufacturing in Eight Developing Countries: Does Business Environment Matter for Firm Technical Efficiency? Journal of Development Studies, 48 (10): 1470-1488.

Coe, D. T. and Helpman, E. 1995. International R\&D spillovers, European Economic Review, 39, 859-887.

Commander, S. and Svejnar, J. 2007. Do Institutions, Ownership, Exporting and Competition Explain Firms' Performances? Evidence for 26 Transition Economies. IZA Discussion Paper 2637. Institute for Study of the Labor reforms.

Commander, S. and Svejnar, J. 2007. Do Institutions, Ownership, Exporting and Competition Explain Firms' Performances? Evidence for 26 Transition Economies. IZA Discussion Paper 2637 (February).

Correa, A. Acosta, M., González, A. and Medina, U. 2003. Size, Age and Activity Sector on the Growth of the Small and Medium Firm Size. Small Business Economics 21(3): 289-307

Barro, R.J. 1990. Government Spending in a Simple Model of Endogenous Growth, Journal of Political Economy, 98 (5): part II, 103-125.

Das, S. 1995. Size, Age and Firm Growth in an Infant Industry: The Computer Hardware Industry in India. International Journal of Industrial Organization 13(1): 111-126.

Dethier, J.J, Hirn, M. and Straub, J. 2008. Explaining Enterprise Performance In Developing Countries With Business Climate Survey Data, World Bank Policy Research Paper 4792. The World Bank: Washington, D.C..

Dollar. D., Hallward-Driemeier, M. and Mengistae, T. 2005. Investment Climate and Firms' Performance in Developing Economies, Economic Development and Cultural Change, 54(1):21.

Engerman, S.L and Sokoloff, K.L. 2002. Factor Endowments, Inequality, and Paths of Development among New World Economics, NBER Working Paper 9259.

Escribano, A. and Guasch, J.L.2005. Assessing the Impact of the Investment Climate on Productivity Using Firm-Level Data: Methodology and the Case of Guatemala, Honduras and Nicaragua, World Bank Policy Research Working Paper 3621. The World Bank, Washington, D.C..

Fisman, R and Svensson, J. 2007. Are Corruption and Taxation Really Harmful to Growth? Firm-Level Evidence. Journal of Development Economics, 83:63-75.

Frankel, J. A. and Romer, D. 1999. Does Trade Cause Growth? American Economic Review 89, 379-399.

Gaviria, A. 2002. Assessing the Effects of Corruption and Crime on Firm Performance: Evidence from Latin America. Emerging Markets Review, 3, 245-268.

Gelb, A., Ramachandran, V., Shah, M., K. and Tuner, G. 2007. What Matters To African Firms? The Relevance of Perception Data. Policy Research Working Paper 4446. The World Bank, Washington, D.C.

Ghani, E. 2010 (ed.) The Service Revolution in South Asia, Oxford University Press. 
Goldberg, P., Khandelwal, A., Pavcnik, N. and Topalova, P. 2009. Trade Liberalization and New Imported Inputs, American Economic Review, 99 (2): 494-500.

Goldberg, P., Khandelwal, A., Pavcnik, N. and Topalova, P. 2010. Imported Intermediate Inputs and Domestic Product Growth: Evidence from India, The Quarterly Journal of Economics, November: 1725-65.

Goldberg, M., Kim, K.W. and Ariano, M. 2014. How Firms Cope with Crime and Violence: Experiences from Around the World. The World Bank: Washington, D.C..

González, A.S. and Lamanna, F. 2007. Who Fears Competition from Informal Firms? Evidence from Latin America, Policy Research Working Paper 4316. The World Bank: Washington, D.C..

Haltiwanger, J., Lane, J. and Spletzer, J. 1999. Productivity Differences across Employers: The Roles of Employer Size, Age, and Human Capital. American Economic Review Papers and Proceedings 89(2): 94-98.

Hanousek, J. and Kochanova, A. 2016 . Bribery Environments and Firm Performance: Evidence from CEE Countries, European Journal of Political Economy, 43 (June):14-28

Holtz-Eakin, D. and Schwartz, A.E. 1995. Spatial Productivity Spillovers from Public Infrastructure: Evidence from State Highways, NBER Working Paper W5004. National Bureau of Economic Research, Cambridge, Massachusetts.

Howitt, P. 2000. Endogenous Growth and Cross-Country Income Differences, American Economic Review 90: 829-846.

Islam, A., 2014. Economic Growth and Crime against Small and Medium Sized Enterprises in Developing Economies, Policy Research Working Paper 6768. The World Bank: Washington, D.C..

Kaldor, N. 1966. Causes of the Slow Rate of Economic Growth in the UK, Cambridge University Press.

Kinda, T., Plane, P. and Véganzonès-Varoudakis, M-A. 2014. Does Investment Climate Matter for Firm's Technical Efficiency? An Application to Middle Eastern and North African Manufacturing, Journal of International Development, 27 (7): 1267-1293.

Koc, T. 2007. The impact of ISO 9000 Quality Management Systems on Manufacturing Journal of Materials Processing Technology, 86 (1-3): 207-213.

La Porta, R. and Shleifer, A. 2014. Informality and Development. NBER Working Paper 20205, (June).

Lima, M., Resende, M. and Hasenclever, L. 2000. Quality Certification and Performance of Brazilian Firms: An Empirical Study, International Journal of Production Economics, 66, (2): 143-147.

Lima, M., Resende, M. and Hasenclever, L. 2004. Skill Enhancement Efforts and Firm Performance in the Brazilian Chemical Industry: An Exploratory Canonical Correlation Analysis, International Journal of Production Economics, 87 (2):149-155.

Lin, J. 2012. New Structural Economics: A Framework for Rethinking Development and Policy. The World Bank: Washington D. C.

Lucas, R.Jr. 1988. On the Mechanics of Economic Development, Journal of Monetary Economics, 22 (1):3-42.

Mankiw, G., Romer, D. and Weil, D. 1992. A Contribution to the Empirics of Economic Growth, Quarterly Journal of Economics, 106:407-37. 
Manly, B.F.J. 1994. Multivariate Statistical Method: A Primer, $2^{\text {nd }}$ ed., Chapman \& Hall, New York.

Mardia, K. V., Kent, J. T. and Bibby, J. M. 1997. Multivariate Analysis, $6^{\text {th }}$ ed., Academic Press, New York.

Mitra, A., Varoudakis, A. and Véganzonès, M-A. 2002. Productivity and Technical Efficiency in Indian States' Manufacturing: The Role of Infrastructures, Economic Development and Cultural Change, 50 (2): 395-426.

Murphy, K.M., Shleifer, A. and Vishny, R.W. 1989. Industrialization and the Big Push, Journal of Political Economy 97 (5): 1003-1026.

OECD (2001). Measuring Productivity. OECD Manuel: Measurement of Aggregate and Industry-Level Productivity Growth. OECD: Paris.

Olson, M. Jr., Sarna, N., and Swamy, A. V. 2000. Governance and growth: a simple hypothesis explaining cross-country differences in productivity growth. Public Choice, 102, 341-364.

Ospina, S. and Schiffbauer M., 2010. Competition and Firm Productivity: Evidence from Firm-Level Data, IMF Working Paper WP/10/67. International Monetary Funds: Washington, D.C..

Pande, R., Udry , C.2005. Institutions and Development: A View from Below. Discussion Paper 928, Yale University Economic Growth Center.

Psacharopoulos, G.1988. Education and Development: A Review, World Bank Research Observer, Oxford University Press, 3(1): 99-116.

Schneider, F. and Enste, D.H. 2000. Shadow Economies: Size, Causes, and Consequences, Journal of Economic Literature XXXVIII (March): 77-114.

Schneider, F., Buehn, A. and Montenegro, C. 2010. Shadow Economies All over the World New Estimates for 162 Countries from 1999 to 2007, Policy Research Working Paper 5356. The World Bank : Washington, D.C..

Shanmugam, K. and Bhaduri, S. 2002. Size, Age and Firm Growth in the Indian Manufacturing Sector. Applied Economics Letters 9(9): 607-613.

Souillard, B. 2016. Innovation, Productivity and Export: the Case of Indian Manufacturing Firms. ENSAEParisTech: Paris.

Stiglitz, J., Lin, J. and Monga, C. 2013. The Rejuvenation of Industrial Policy. Policy Working Paper 6628. The World Bank: Washington, D.C.

Straub, S. 2011. Infrastructure and Development: a Critical Appraisal of the Macro-level Literature, The Journal of Development Studies, 47 (5): 683-708.

Svensson, J. 1998. Investment, property rights and political instability: Theory and evidence. European Economic Review, 42 (7): 1317-1341.

Topalova, P. and Khandelwal, A. 2011. Trade Liberalization and Firm Productivity: The Case of India, The Review of Economics and Statistics, 93, 995-1009.

Tanzi, V. and Davooli, H.1997. Corruption, Public Investment, and Growth, IMF Working Papers 97/139, IMF: Washington, D.C. 
Wang Y. and You J. 2012. Corruption and firm growth: Evidence from China, China Economic Review, 23 (2): 415-433.

World Bank. 1994. World Development Report 1995: Infrastructure for Development. The World Bank: Washington, D.C.

World Bank, 2004. World Development Report 2005: A Better Investment Climate for Everyone. The World Bank and Oxford University Press, Washington, D.C.

World Bank, 2007. World Development Report 2008: Development and the Next Generation. The World Bank: Washington, D.C..

World Bank, 2011. World Development Report 2012: Conflict, Security and Development. The World Bank: Washington, D.C..

World Bank, 2016. Doing Business. The World Bank: Washington, D.C.

World Bank, 2017. World Development Report 2018: Getting education right—and fulfilling its promise as a driver of development. The World Bank: Washington, D.C.. 


\section{Annex 1}

\section{Table-A1: List of countries of the Sample}

\begin{tabular}{|c|c|c|}
\hline $\begin{array}{c}\begin{array}{c}\text { Sub-Sahara } \\
\text { Africa }\end{array} \\
\end{array}$ & South-Asia & $\begin{array}{c}\text { East \& } \\
\text { South-East Asia } \\
\end{array}$ \\
\hline Angola $(2006 / 2010)$ & Bangladesh (2007 /2013) & Cambodia (2013 /2016) \\
\hline Botswana (2006 /2010) & Bhutan (2009 /2015) & Indonesia (2009 /2015) \\
\hline Burkina Faso (2006 /2009) & Nepal (2009 /2013) & Lao PDR (2009 /2016) \\
\hline Cameroon (2006 /2009) & Pakistan (2007 /2013) & Mongolia (2009 /2013) \\
\hline Congo (2010 /2013) & & Philippines (2009 /2015) \\
\hline Ethiopia (2011/2015) & & Timor-Leste (2009 /2015) \\
\hline Kenya (2007 /2013) & & Vietnam (2009 /2015) \\
\hline \multicolumn{3}{|l|}{ Malawi (2009 /2014) } \\
\hline \multicolumn{3}{|l|}{ Mali (2007 /2010) } \\
\hline \multicolumn{3}{|l|}{ Nigeria $(2007$ /2014) } \\
\hline \multicolumn{3}{|l|}{ Senegal (2007 /2014) } \\
\hline \multicolumn{3}{|l|}{ South Africa (2007 /2014) } \\
\hline \multicolumn{3}{|l|}{ Tanzania $(2006 / 2013)$} \\
\hline \multicolumn{3}{|l|}{ Uganda (2006 /2013) } \\
\hline $\begin{array}{c}\text { Central } \\
\text { Asia }\end{array}$ & $\begin{array}{c}\text { Latin } \\
\text { America }\end{array}$ & $\begin{array}{c}\text { Middle-East } \\
\text { \& North-Africa }\end{array}$ \\
\hline Armenia (2009 /2013) & Argentina (2006 /2010) & Egypt (2008 /2013) \\
\hline Azerbaijan (2009/2013) & Bolivia (2006 /2010) & Morocco (2004 /2007) \\
\hline Georgia $(2008$ /2013) & Brazil (2003 /2009) & Yemen $(2010 / 2013)$ \\
\hline Kazakhstan (2009 /2013) & Chile (2006 /2010) & \\
\hline Kyrgyz Rep (2009 /2013) & Colombia (2006 /2010) & \\
\hline Tajikistan (2008 /2013) & Ecuador (2006 /2010) & \\
\hline Turkey (2008 /2013) & El Salvador (2006 2010) & \\
\hline \multirow[t]{9}{*}{ Uzbekistan (2008 /2013) } & Guatemala (2006/2010) & \\
\hline & Honduras (2006 /2010) & \\
\hline & Mexico (2006 /2010) & \\
\hline & Nicaragua (2006 /2010) & \\
\hline & Panama $(2006 / 2010)$ & \\
\hline & Paraguay (2006 /2010) & \\
\hline & Peru $(2006 / 2010)$ & \\
\hline & Uruguay (2006 /2010) & \\
\hline & Venezuela $(2006$ /2010) & \\
\hline
\end{tabular}

Note: Years of survey are into brackets 


\section{Annex 2}

\section{The Investment Climate Composite Indicators}

\section{Infrastructure quality}

The infrastructure indicator (Infra) is defined by 4 variables:

(a) Does the firm experiment power shortages $(Y e s=1 / N o=2)$ ?

(b) Does the firm own or share a generator $(Y e s=1 / N o=2)$ ?

Obstacle $^{22}$ for the operation of the enterprise caused by deficiencies in:

(c) Electricity (1 to 4)

(d) Transport (1 to 4)

In the developing world, electricity is identified as a major constraint for firms' operations (see section 5). This justifies that this sector is well documented in the surveys. It is also why we could complement the subjective information contained in the variable "obstacle" by the more objective one incorporated in the variables "power shortages" and "generator utilization". In line with the literature, this last variable is considered as proxy of power outages.

The Infrastructure index (Infra) has been constructed as a factor facilitating firms' performance. The variables have been entered into the aggregate indicator with the sign appropriated to this interpretation.

\section{ICT availability}

The ICT indicator is composed of 3 variables:

In its interaction with clients and suppliers, does the enterprise have access to:

(a) E-mail $(Y e s=1 / N o=2)$ ?

(b) Internet $(Y e s=1 / N o=2)$ ?

(c) Obstacle for the operation of the enterprise caused by deficiencies in telecommunications ( 1 to 4 ).

Here as well, we have complemented the variable "obstacle" with 2 more objective ones: the use of email and of internet. The 3 variables enter into the composite indicator with a negative sign.

\footnotetext{
${ }^{22}$ Firms are asked to position their answer on a scale going from $\mathbf{1}$ (no obstacle) to $\mathbf{4}$ (very severe obstacle).
} 


\section{Human capacity}

The human capacity indicator $(H)$ is represented by 2 variables:

(a) Number of years of experience of the top manager (years).

(b) Training of the firm's employees (Yes=1/ $N o=2)$ ?

The 2 variables enter into the composite indicator with opposite signs.

\section{Financing ability}

The financing indicator (Fin) consists of 3 variables:

(a) Percentage of inputs purchased on credit (\%)

(b) Access to an overdraft facility or a line of credit $(Y e s=1 / N o=2)$ ?

(c) Obstacle for the operation of the enterprise caused by the access to financing ( 1 to 4 ).

The variable "obstacle" is counterbalanced by 2 more objective ones. The variable "inputs purchased on credit" enter into the composite indicator with an opposite sign to the 2 other ones ("access to an overdraft facility" and "obstacle for the firm").

\section{Government relation}

The government relations indicator (Gov) includes 8 variables:

(a) Has the firm been inspected by tax officials $(Y e s=1 / N o=2)$ ?

(b) Percentage of time spent to deal with government regulations (\%).

(c) Has a gift been given when inspected by tax officials $(Y e s=1 / \mathrm{No}=2)$ ?

Obstacle for the operation of the enterprise caused by:

(d)Tax rate (1 to 4$)$.

(e) Tax administration (1 to 4).

(f) Labor regulation (1 to 4).

(g) Business licensing and operating permits (1 to 4).

(h) Corruption (1 to 4 )

Despite the debate on the role of corruption and regulation on firms' productive performance (see section 5), empirical evidence shows more often a negative impact of these 2 factors. Accordingly, we 
have entered the variables "inspections" and "gift to inspectors" with the opposite sign to the other variables.

\section{Security and political stability}

The security and political stability indicator ( $\mathrm{CrimePol})$ is formed of 4 variables:

(a) Is the firms paying to ensure its security $(Y e s=1 / N o=2)$ ?

(b) Has the firm experimented losses due to robbery $(Y e s=1 / N o=2)$ ?

Obstacle for the operation of the enterprise caused by:

(c) Crime (1 to 4).

(d) Political instability (1 to 4).

The 2 variables of obstacle, and the 2 other ones ("paying for security" and "losses due to robbery") enter the composite indicator with opposite signs.

\section{Competition}

The competition indicator (Comp) consists in 2 variables:

(a) Is the enterprise main market local (1), national (2) or international (3)?

(b) Obstacle for the operation of the enterprise caused by the presence of the informal sector (1 to 4).

The 2 variables contribute to the composite indicator with opposite direction. 


\section{Annex 3}

\section{Table-A2 Investment Climate and Firms Characteristics: Descriptive Statistics}

\begin{tabular}{|c|c|c|c|c|c|}
\hline Variable & Nobs & Mean & $\begin{array}{l}\text { Std. } \\
\text { Dev. }\end{array}$ & Min & Max \\
\hline log (Value Added in US dollars) & 11887 & 13,4 & 2,5 & 5,24 & 24,43 \\
\hline Permanent, Full-Time Employees & 15676 & 140,5 & 512,7 & 0 & 21000 \\
\hline Size (Small, Medium, Big) & 15764 & 2,0 & 0,8 & 1 & 3 \\
\hline Age of firm (years) & 15514 & 22,1 & 17,6 & 0 & 184 \\
\hline Export (\% of sales) & 15373 & 14,5 & 29,4 & 0 & 100 \\
\hline Export (Yes/No) & 15373 & 0,33 & 0,47 & 0 & 1 \\
\hline Foreign Capital (Yes/No) & 15231 & 0,12 & 0,33 & 0 & 1 \\
\hline Did This Establishment Experience Power Outages? (Yes/No) & 14943 & 1,39 & 0,49 & 1 & 2 \\
\hline Generator Shared Or Owned ? (Yes/No) & 14879 & 1,69 & 0,46 & 1 & 2 \\
\hline How Much of an Obstacle is Electricity? & 15652 & 1,81 & 1,55 & 0 & 4 \\
\hline How Much of an Obstacle is Transportation of Goods, Supplies, and Inputs? & 15583 & 1,23 & 1,27 & 0 & 4 \\
\hline Do You Currently Communicate with Clients and Suppliers by E-Mail? (Yes/No) & 15658 & 1,30 & 0,46 & 1 & 2 \\
\hline Do You Currently Communicate with Clients and Suppliers via Website? (Yes/No) & 15679 & 1,55 & 0,50 & 1 & 2 \\
\hline How Much of an Obstacle are Telecommunications? & 9669 & 0,96 & 1,22 & 0 & 4 \\
\hline How Many Years of Experience Working in this Sector does the Top Manager Have? & 15372 & 18,5 & 11,8 & 0 & 74 \\
\hline Formal Training Programs for Permanent, Full-Time Employees ? (Yes/No) & 14660 & 1,61 & 0,49 & 1 & 2 \\
\hline$\%$ of Material Inputs or Services Purchases Paid for after Delivery & 13449 & 0,49 & 0,40 & 0 & 1 \\
\hline Does this Establishment Have an Overdraft Facility? (Yes/No) & 14108 & 1,53 & 0,50 & 1 & 2 \\
\hline How Much of an Obstacle Is Access to Finance? & 14645 & 1,56 & 1,37 & 0 & 4 \\
\hline Was this Establishment Inspected by Tax Officials? & 15108 & 1,40 & 0,49 & 1 & 2 \\
\hline What $\%$ of Senior Management Time Was Spent in Dealing with Govt Regulations? & 14798 & 11,2 & 17,82 & 0 & 100 \\
\hline In Any of these Inspections Was a Gift or Informal Requested ? (Yes/No) & 14891 & 1,91 & 0,28 & 1 & 2 \\
\hline How Much of an Obstacle are Tax Rates? & 15512 & 1,85 & 1,37 & 0 & 4 \\
\hline How Much of an Obstacle is Tax Administration? & 15394 & 1,47 & 1,32 & 0 & 4 \\
\hline How Much of an Obstacle are Business Licensing and Permits? & 15050 & 1,09 & 1,23 & 0 & 4 \\
\hline How Much of an Obstacle is Political Instability? & 14081 & 1,67 & 1,50 & 0 & 4 \\
\hline How Much of an Obstacle is Corruption? & 15165 & 1,76 & 1,52 & 0 & 4 \\
\hline How Much Of An Obstacle are Labor Regulations? & 15574 & 1,20 & 1,27 & 0 & 4 \\
\hline How Much of an Obstacle is Inadequately Educated Workforce? & 15519 & 1,47 & 1,33 & 0 & 4 \\
\hline Did this Establishment Pay for Security? (Yes/No) & 15764 & 1,37 & 0,48 & 1 & 2 \\
\hline Losses Due To Theft, Robbery, Vandalism Or Arson Experienced? (Yes/No) & 15764 & 1,70 & 0,46 & 1 & 2 \\
\hline How Much of and Obstacle are Crime, Theft and Disorder? & 15524 & 1,26 & 1,33 & 0 & 4 \\
\hline Main Mkt in which You Sold Your Main Product or Service & 12252 & 1,68 & 0,68 & 1 & 3 \\
\hline How Much of an Obstacle are the Informal Sector Competitors? & 14833 & 1,70 & 1,43 & 0 & 4 \\
\hline
\end{tabular}




\section{Annex 4}

Table-A3a- Production Function with Composite Indicators of

Predicted Value of Business Environment Variables ${ }^{\wedge \wedge}$ : Estimation Results by Sector (1)

(Dependant Variable: Log of Firm Value-Added)

\begin{tabular}{|c|c|c|c|c|c|c|c|c|c|c|c|}
\hline Sectors & Food & Food & Food & Food & Food & Food & Textile & Garment & Leather & Leather & $\begin{array}{c}\text { Wood } \\
\text { Furniture }\end{array}$ \\
\hline $\mathbf{L}$ & $\begin{array}{c}0.658 * * * \\
(13.68)\end{array}$ & $\begin{array}{c}0.628 * * * \\
(11.72)\end{array}$ & $\begin{array}{c}0.674 * * * \\
(14.61)\end{array}$ & $\begin{array}{c}0.636 * * * \\
(12.44)\end{array}$ & $\begin{array}{c}0.632 * * * \\
(13.45)\end{array}$ & $\begin{array}{c}0.598 * * * \\
(11.57)\end{array}$ & $\begin{array}{c}0.740 * * * \\
(9.23)\end{array}$ & $\begin{array}{c}0.713 * * * \\
(15.39)\end{array}$ & $\begin{array}{c}0.676^{* * *} * \\
(9.46)\end{array}$ & $\begin{array}{c}0.806^{* * *} \\
(8.12)\end{array}$ & $\begin{array}{c}\mathbf{0 . 9 8 1} * * * \\
(13.58)\end{array}$ \\
\hline $\mathbf{K}$ & $\begin{array}{c}0.222^{* * *} * \\
(9.19)\end{array}$ & $\begin{array}{c}0.222^{* * *} * \\
(9.15)\end{array}$ & $\begin{array}{l}0.218 * * * \\
(9.08)\end{array}$ & $\begin{array}{c}0.218 * * * \\
(9.03) \\
-\end{array}$ & $\begin{array}{c}0.219 * * * \\
(9.11)\end{array}$ & $\begin{array}{c}0.218 * * * \\
(9.06) \\
-\end{array}$ & $\begin{array}{c}0.225^{* * * *} \\
(8.11)\end{array}$ & $\begin{array}{c}0.224 * * * \\
(10.18)\end{array}$ & $\begin{array}{c}0.183^{* * * *} \\
(6.20)\end{array}$ & $\begin{array}{c}0.164 * * * \\
(5.27)\end{array}$ & $\begin{array}{c}0.194^{* * *} \\
(6.58)\end{array}$ \\
\hline Year & $\begin{array}{c}-0,032 * \\
(-2.23)\end{array}$ & $\begin{array}{c}-0,039 * * \\
(-2.60)\end{array}$ & $\begin{array}{c}-0,037 * * \\
(-2.79)\end{array}$ & $\begin{array}{c}0,046^{* * *} \\
(-3.30)\end{array}$ & $\begin{array}{c}-0,045^{* *} \\
(-3.27)\end{array}$ & $\begin{array}{c}0,053 * * * \\
(-3.75)\end{array}$ & & & & & \\
\hline Age & & & & & & & & $\begin{array}{c}0,005 * * * \\
(3.31)\end{array}$ & & & \\
\hline Quality Certification $^{\wedge}$ & $\begin{array}{c}0.200 * \\
(2.34)\end{array}$ & $\begin{array}{c}0.197 * \\
(2.31)\end{array}$ & $\begin{array}{c}0.198 * \\
(2.32)\end{array}$ & $\begin{array}{c}0.194 * \\
(2.28)\end{array}$ & $\begin{array}{c}0.178 * \\
(2.09)\end{array}$ & $\begin{array}{c}0.174 * \\
(2.04)\end{array}$ & $\begin{array}{c}0.240 * \\
(2.21)\end{array}$ & $\begin{array}{c}0.193^{*} \\
(2.56)\end{array}$ & $\begin{array}{c}0.266 * \\
(2.58)\end{array}$ & $\begin{array}{c}0.262 * \\
(2.53)\end{array}$ & $\begin{array}{c}0.381 * * * \\
(4.26)\end{array}$ \\
\hline Foreign Lic Tech $^{\wedge}$ & $\begin{array}{l}0.118 \\
(1.26)\end{array}$ & $\begin{array}{l}0.119 \\
(1.28)\end{array}$ & $\begin{array}{l}0.127 \\
(1.36)\end{array}$ & $\begin{array}{l}0.129 \\
(1.39)\end{array}$ & $\begin{array}{l}0.115 \\
(1.22)\end{array}$ & $\begin{array}{l}0.115 \\
(1.23)\end{array}$ & $\begin{array}{l}0.106 \\
(0.96)\end{array}$ & $\begin{array}{l}0.133 \\
(1.51)\end{array}$ & $\begin{array}{l}0.121 \\
(1.13)\end{array}$ & $\begin{array}{l}0.105 \\
(0.94)\end{array}$ & $\begin{array}{c}0.235^{*} \\
(2.14)\end{array}$ \\
\hline $\mathbf{X}^{\wedge}$ & $\begin{array}{c}0.397 * * * \\
(4.92)\end{array}$ & $\begin{array}{c}0.392 * * * \\
(4.86)\end{array}$ & $\begin{array}{c}0.405^{* * * *} \\
(5.03)\end{array}$ & $\begin{array}{c}0.398 * * * \\
(4.96)\end{array}$ & $\begin{array}{c}0.388 * * * \\
(4.84)\end{array}$ & $\begin{array}{c}0.382 * * * \\
(4.78)\end{array}$ & $\begin{array}{c}0.165^{*} \\
(1.90)\end{array}$ & $\begin{array}{c}0.0522 \\
(1.78)\end{array}$ & $\begin{array}{c}0.281 * * \\
(3.20)\end{array}$ & $\begin{array}{c}0.307 * * * \\
(3.35)\end{array}$ & $\begin{array}{c}0.318 * * * \\
(3.93)\end{array}$ \\
\hline Foreign_K$^{\wedge}$ & $\begin{array}{c}0.291 * * \\
(2.85)\end{array}$ & $\begin{array}{c}0.285^{* *} * \\
(2.80)\end{array}$ & $\begin{array}{c}0.311^{* *} \\
(3.07)\end{array}$ & $\begin{array}{c}0.304 * * \\
(3.01)\end{array}$ & $\begin{array}{c}0.303^{* *} \\
(2.97)\end{array}$ & $\begin{array}{c}0.297 * * \\
(2.92)\end{array}$ & $\begin{array}{c}0.481^{* * * *} \\
(3.48)\end{array}$ & $\begin{array}{c}0.0943 \\
(1.80)\end{array}$ & $\begin{array}{c}0.388 * * \\
(2.68)\end{array}$ & $\begin{array}{c}0.423^{* *} * \\
(2.81)\end{array}$ & $\begin{array}{c}0.350^{* *} * \\
(2.89)\end{array}$ \\
\hline H_PCA ${ }^{\wedge \wedge}$ & $\begin{array}{c}0.294 * * * \\
(4.01)\end{array}$ & $\begin{array}{c}0.301 * * * \\
(4.09)\end{array}$ & $\begin{array}{c}0.333 * * * \\
(4.85)\end{array}$ & $\begin{array}{c}0.340 * * * \\
(4.94)\end{array}$ & $\begin{array}{c}0.279 * * * \\
(4.02)\end{array}$ & $\begin{array}{c}0.284 * * * \\
(4.08)\end{array}$ & $\begin{array}{l}0.119 \\
(1.52)\end{array}$ & $\begin{array}{c}0.226^{* * * *} \\
(3.67)\end{array}$ & $\begin{array}{l}0.119 \\
(1.43)\end{array}$ & & \\
\hline Exp. Manager & & & & & & & & & & $\begin{array}{c}0.0488^{*} \\
(2.11)\end{array}$ & $\begin{array}{c}0.0244 \\
(1.63)\end{array}$ \\
\hline Fin_PCA $A^{\wedge \wedge}$ & $\begin{array}{c}0.345^{* * *} \\
(4.40)\end{array}$ & $\begin{array}{c}0.332 * * * \\
(4.34)\end{array}$ & $\begin{array}{c}0.264 * * * \\
(3.33)\end{array}$ & $\begin{array}{c}0.250 * * \\
(3.23)\end{array}$ & $\begin{array}{c}0.281 * * * \\
(3.71)\end{array}$ & $\begin{array}{c}0.268 * * * \\
(3.64)\end{array}$ & $\begin{array}{c}0.530 * * * \\
(6.41)\end{array}$ & $\begin{array}{c}0.460 * * * \\
(7.82)\end{array}$ & $\begin{array}{c}0.512 * * * \\
(6.50)\end{array}$ & $\begin{array}{c}0.459 * * * \\
(5.05)\end{array}$ & $\begin{array}{c}0.348 * * * \\
(4.40)\end{array}$ \\
\hline Infra_PCA ${ }^{\wedge \wedge}$ & $\begin{array}{c}0.0958^{* *} * \\
(2.76)\end{array}$ & & $\begin{array}{c}0.114 * * \\
(3.24)\end{array}$ & & $\begin{array}{c}0.0877 * \\
(2.56)\end{array}$ & & & & & & \\
\hline Generator $^{\wedge}$ & & $\begin{array}{c}0.450 * \\
(1.98)\end{array}$ & & $\begin{array}{c}0.665 * * \\
(2.95)\end{array}$ & & $\begin{array}{c}0.544 * \\
(2.48)\end{array}$ & $\begin{array}{c}1.967 * * * \\
(5.74)\end{array}$ & $\begin{array}{c}0.576^{*} \\
(2.34)\end{array}$ & $\begin{array}{c}1.996^{* * *} \\
(3.95)\end{array}$ & $\begin{array}{l}1.517 * \\
(2.58)\end{array}$ & $\begin{array}{l}0.374 \\
(1.10)\end{array}$ \\
\hline ICT_PCA ${ }^{\wedge} \wedge$ & $\begin{array}{c}0.135^{*} \\
(2.11)\end{array}$ & $\begin{array}{c}0.132 * \\
(2.04)\end{array}$ & & & & & & & & & \\
\hline E-mail ${ }^{\wedge}$ & & & $\begin{array}{c}0.939 * * * \\
(4.36)\end{array}$ & $\begin{array}{c}0.927 * * * \\
(4.24)\end{array}$ & & & $\begin{array}{c}1.207 * * * \\
(4.41)\end{array}$ & & & $\begin{array}{l}-0.328 \\
(-0.65)\end{array}$ & $\begin{array}{c}0.816^{*} \\
(2.55)\end{array}$ \\
\hline Web $^{\wedge}$ & & & & & $\begin{array}{c}1.132 * * * \\
(5.11)\end{array}$ & $\begin{array}{c}1.159 * * * \\
(5.23)\end{array}$ & & $\begin{array}{c}1.537 * * * \\
(7.55)\end{array}$ & & & \\
\hline Corruption $^{\wedge}$ & $\begin{array}{c}1.652 * * * \\
(3.49)\end{array}$ & $\begin{array}{c}1.679 * * * \\
(3.44)\end{array}$ & $\begin{array}{c}1.464 * * \\
(3.10)\end{array}$ & $\begin{array}{c}1.505 * * \\
(3.09)\end{array}$ & $\begin{array}{c}1.358 * * \\
(2.84)\end{array}$ & $\begin{array}{c}1.395 * * \\
(2.83)\end{array}$ & $\begin{array}{c}1.936^{* * * *} \\
(3.65)\end{array}$ & $\begin{array}{c}0.984 * * \\
(2.65)\end{array}$ & & $\begin{array}{l}-0.919 \\
(-0.85)\end{array}$ & $\begin{array}{c}2.95 * * * \\
(4.86)\end{array}$ \\
\hline CrimPol_PCA $^{\wedge} \wedge$ & $\begin{array}{c}0.251^{* * * *} \\
(3.31)\end{array}$ & $\begin{array}{c}0.217 * * \\
(2.93)\end{array}$ & $\begin{array}{c}0.312^{* * * *} \\
(4.04)\end{array}$ & $\begin{array}{c}0.271 * * * \\
(3.61)\end{array}$ & $\begin{array}{c}0.277^{* * * *} \\
(3.71)\end{array}$ & $\begin{array}{c}0.250 * * * \\
(3.42)\end{array}$ & & & & & \\
\hline $\begin{array}{l}\text { Roberies }^{\wedge} \\
\text { Comp_PCA }^{\wedge \wedge}\end{array}$ & & & & & & & $\begin{array}{c}1.884 * * * \\
(4.40)\end{array}$ & $\begin{array}{c}0.787 * * \\
(2.79)\end{array}$ & & $\begin{array}{c}-0.40 \\
(-0.53)\end{array}$ & $\begin{array}{c}0.719 * \\
(1.90)\end{array}$ \\
\hline Market size & & & & & & & $\begin{array}{c}0.731 * \\
(2.11)\end{array}$ & $\begin{array}{c}1.226^{* * * *} \\
(4.46)\end{array}$ & $\begin{array}{c}1.185^{* * *} * \\
(3.32)\end{array}$ & $\begin{array}{c}1.521 * * * \\
(3.67)\end{array}$ & $\begin{array}{c}1.203 * * * \\
(3.94)\end{array}$ \\
\hline Intercept & $\begin{array}{l}70,6^{*} \\
(2.47) \\
\end{array}$ & $\begin{array}{c}84,2 * * \\
(2.84) \\
\end{array}$ & $\begin{array}{c}80,8 * * \\
(3.04) \\
\end{array}$ & $\begin{array}{c}97,7 * * * \\
(3.54)\end{array}$ & $\begin{array}{c}96,7 * * * \\
(3.52)\end{array}$ & $\begin{array}{c}112,4 * * * \\
(4.00) \\
\end{array}$ & $\begin{array}{c}3,6^{* * * *} \\
(5.32) \\
\end{array}$ & $\begin{array}{l}5,2 * * * \\
(13.46) \\
\end{array}$ & $\begin{array}{c}7,7 * * * \\
(17.21) \\
\end{array}$ & $\begin{array}{c}7,5 * * * \\
(8.97) \\
\end{array}$ & $\begin{array}{l}2,2 * * \\
(3.15) \\
\end{array}$ \\
\hline ProbaCRScale & 0.004 & 0.002 & 0.004 & 0.001 & 0.00 & 0.00 & 0.61 & 0.17 & 0.04 & 0.76 & 0.01 \\
\hline 'e K/e L & 0,34 & 0,35 & 0,32 & 0,34 & 0,35 & 0,36 & 0,30 & 0,31 & 0,27 & 0,20 & 0,20 \\
\hline $\mathbf{R}^{2}$ & 0,75 & 0,75 & 0,76 & 0,76 & 0,76 & 0,76 & 0,78 & 0,82 & 0,82 & 0,83 & 0,84 \\
\hline Observations & 1542 & 1562 & 1542 & 1542 & 1542 & 1542 & 857 & 1273 & 568 & 540 & 834 \\
\hline
\end{tabular}


Table-A3b- Production Function with Composite Indicators of Predicted Value of Business Environment Variables $^{\wedge \wedge \wedge}$ : Estimation Results by Sector (2) (Dependant Variable: Log of Firm Value-Added)

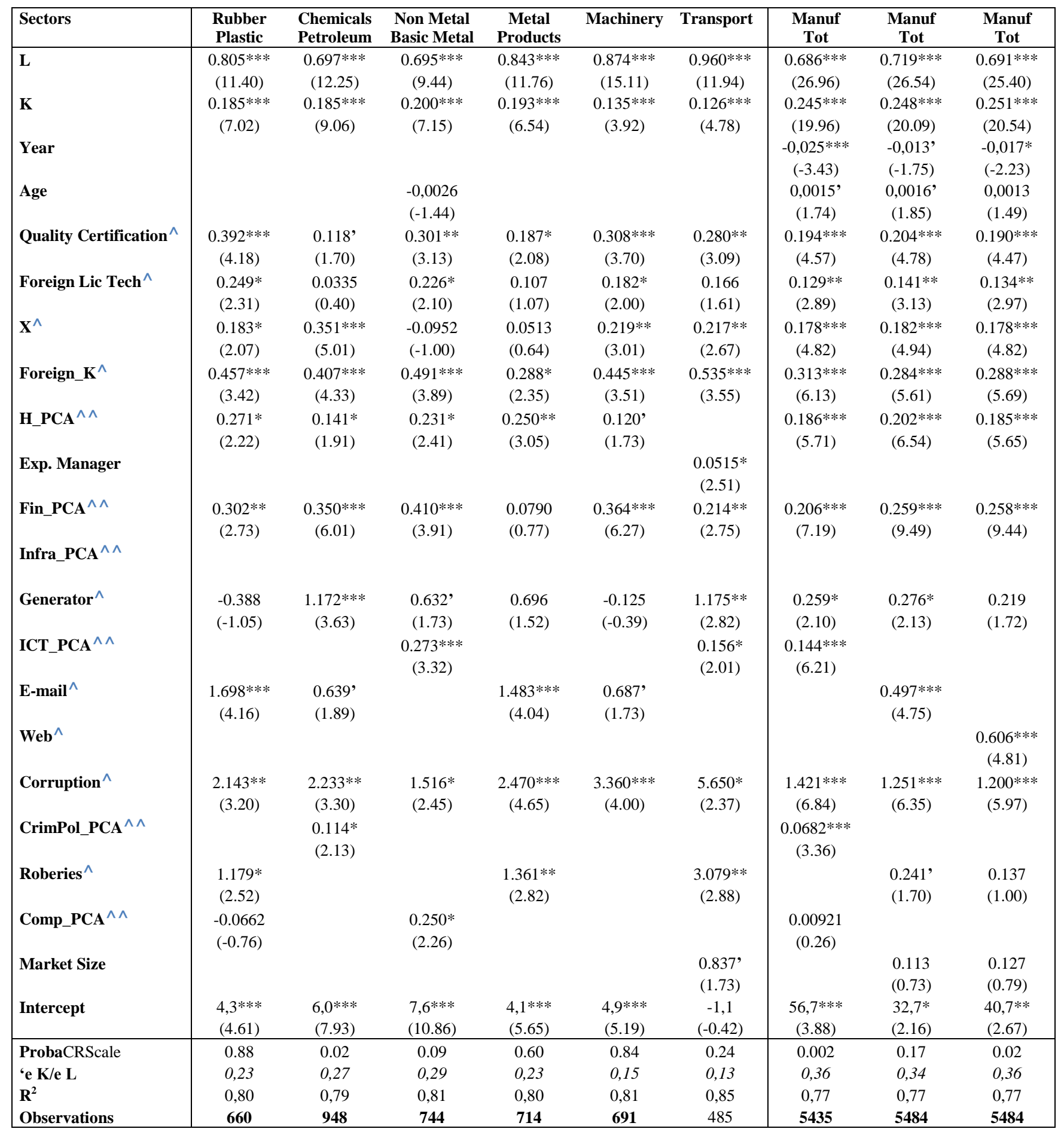

For table-A3a and A3b. Source: Authors' estimations.

Note: K: capital (in log); L: labor (in log); Year: year of survey; Age: firm's age (in years) ; Cert: quality certification; Lic: foreign licensed technology; Export: export status; Foreign_K: foreign ownership of capital; Exp. Manager: experience of the top manager (in years); Generator: share/own generator; E-mail \& Web: access to e-mail and internet; Corruption: gift when inspected; Roberies: losses due to robberies; Market Size: local, national or international; Infra, ICT, H, Fin, Gov, CrimePol, Comp: investment climate (IC) composite indicators (see Annex 2 for their definition). The expected sign of the $I C$ composite indicators is positive). Variables Age, Cert, Lic, Foreign, Export, Training, Exp. Manager, Generator and Corruption are also expected to have a positive coefficient. Regressions contain country, region and sector fixed-effects. Production functions are estimated by a pool OL.S Heteroskedasticity-robust $\mathrm{t}$-students are reported in parentheses. $* * *, * *$, and ${ }^{\prime}$ denote significance at the $0.1 \%, 1 \%, 5 \%$, and 
$10 \%$, respectively. ${ }^{\wedge}$ Binary variable. ${ }^{\wedge} \wedge$ Aggregated indicator. ${ }^{\wedge} \wedge \wedge$ Business environment variables are replaced by their prediction before entering the composite indicators (see above for details on instrumentation). e K: elasticity of capital ; e L: elasticity of labor; CR: constant returns. 